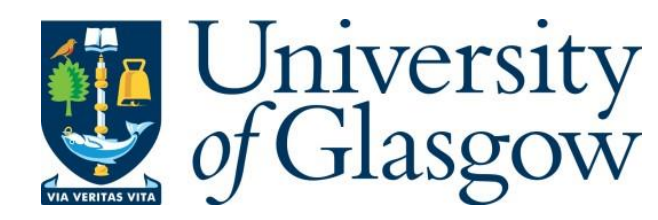

Laskar, P., Somani, S., Campbell, S. J., Mullin, M., Keating, P., Tate, R. J., Irving, C., Leung, H. Y. and Dufès, C. (2019) Camptothecin-based dendrimersomes for gene delivery and redox-responsive drug delivery to cancer cells. Nanoscale, 11(42), pp. 20058-20071.

There may be differences between this version and the published version. You are advised to consult the publisher's version if you wish to cite from it.

http://eprints.gla.ac.uk/201505/

Deposited on: 2 September 2021

Enlighten - Research publications by members of the University of Glasgow http://eprints.gla.ac.uk 


\section{Camptothecin-based dendrimersomes for gene delivery and redox-responsive drug delivery to cancer cells}

Partha Laskart, Sukrut Somanit, Sara Jane Campbell ${ }^{\dagger}$, Margaret Mullin ${ }^{\star}$, Patricia Keatingt, Rothwelle J. Tatè , Craig Irving ${ }^{\dagger}$ Hing Y. Leung ${ }^{\S}$, Christine Dufès ${ }^{\dagger}$ *

${ }^{\dagger}$ Strathclyde Institute of Pharmacy and Biomedical Sciences, University of Strathclyde, 161 Cathedral Street, Glasgow G4 0RE, United Kingdom

${ }^{\&}$ College of Medical, Veterinary and Life Sciences, University of Glasgow, Glasgow G12 8QQ, United Kingdom

Department of Pure and Applied Chemistry, University of Strathclyde, 295 Cathedral Street, Glasgow G1 1XL, United Kingdom

$\S$ Cancer Research UK Beatson Institute, Garscube Estate, Switchback Road, Bearsden, Glasgow, G61 1BD, United Kingdom

\section{Corresponding Author}

* Corresponding author: Christine Dufès

Strathclyde Institute of Pharmacy and Biomedical Sciences, University of Strathclyde, 161 Cathedral Street, Glasgow G4 0RE, United Kingdom

Phone: 44 -141 5483796

Fax: $44-1415522562$

E-mail: C.Dufes@strath.ac.uk 


\begin{abstract}
Combination therapy involving chemotherapeutic drugs and genes is emerging as a promising strategy to provide a synergistic therapeutic effect, to overcome drug resistance while reducing the severe side effects associated with conventional chemotherapeutic drugs. However, the lack of nanomedicines able to simultaneously carry anti-cancer drugs and nucleic acids limits the application of this therapeutic strategy. To overcome this issue, we proposed to synthesize a prodrug dendrimer by conjugating the PEGylated, positively charged generation 3-diaminobutyric polypropylenimine dendrimer to the anti-cancer drug camptothecin with a redox-sensitive disulphide linkage, and evaluate its efficacy to co-deliver the complexed DNA and camptothecin to cancer cells. This PEGylated pro-drug dendrimer was found to spontaneously self-assemble into cationic $(\sim 3-5 \mathrm{mV})$ vesicles at $\mathrm{pH} 7.4$, at a critical aggregation concentration of about 200 $\mu \mathrm{g} / \mathrm{mL}$. These vesicles (dendrimersomes) became smaller (150-200 nm) with increasing dendrimer concentration and remained stable over 7 days. They were able to release about $70 \%$ of the conjugated camptothecin in presence of $50 \mathrm{mM}$ glutathione (equivalent to the intracellular environment of tumor tissue). They could also condense more than $85 \%$ of the DNA at dendrimer: DNA weight ratios of 5:1 and higher. DNA condensation occurred instantly and was found to be stable for at least $24 \mathrm{~h}$. This led to an enhanced cellular uptake of DNA (by up to 1.6fold) and increased gene transfection (by up to 2.4-fold) in prostate cancer cells in comparison with the unmodified dendrimer. These novel dendrimersomes are therefore promising for single carrier-based combination cancer therapy.
\end{abstract}

Keywords: Camptothecin, PEG, dendrimersomes, redox responsiveness, drug and gene delivery 


\section{Introduction}

The combination of chemotherapy and gene therapy within nanomedicines has the potential to provide a synergistic therapeutic effect, to overcome drug resistance while limiting the severe side effects generally associated with traditional anti-cancer drugs. ${ }^{1-3}$ However, the lack of delivery systems able to simultaneously carry anti-cancer drugs and nucleic acids and to selectively deliver them to cancer tissues without secondary effects still limits the application of this therapeutic strategy. ${ }^{2-4}$ To overcome this issue, we propose to synthesize a pro-drug dendrimer by conjugating the PEGylated, positively charged generation 3-diaminobutyric polypropylenimine (DAB) dendrimer to the anti-cancer drug camptothecin (CPT) with a redoxsensitive disulphide linkage, and evaluate its efficacy to co-deliver the complexed DNA along with CPT to cancer cells.

Cationic dendrimers have recently been reported as promising non-viral carriers for nucleic acid and drug delivery to cancer cells..$^{5-7}$ These three-dimensional macromolecules present the advantages of being highly branched, with modifiable surface functionalities leading to the successful conjugation of targeting moieties and the binding of drugs or nucleic acids for therapeutic applications..$^{5-7}$ Due to their positive charge, cationic dendrimers not only can form stable dendriplexes with negatively charged genetic materials, but can also easily bind to the negatively charged cell surface followed by cellular internalization via endocytosis through electrostatic interactions. ${ }^{5-7}$ Furthermore, their high aqueous solubility, low toxicity and compact globular shapes, with internal cavities delimited by constitutive dendrons make these dendrimers ideal carriers for therapeutic agents, facilitating the passive targeting of anticancer drugs to tumor tissues due to the enhanced permeability and retention (EPR) effect. ${ }^{8}$ In this work, generation 3 diaminobutyric polypropylenimine (DAB) dendrimer was selected due to its higher gene transfection efficacy compared with the other generations of polypropylenimine dendrimers. The tumor-targeted generation-3 DAB dendrimer complexed to therapeutic plasmid DNA on mice models has previously led to tumor regression and even tumor suppression on various cancer cell types. ${ }^{9-12}$ In addition, polyethylene glycol (PEG) is a well-known stealth material to enhance circulatory lifetime of any drug and gene delivery systems by increasing their water solubility and reducing non-specific interactions with circulatory proteins. ${ }^{13-16}$ Recently, we observed that the conjugation of low-molecular-weight PEG $(2 \mathrm{kDa})$ to generation 3- and generation 4-DAB 
dendrimers significantly reduced their cytotoxicity, thereby increasing gene expression in various cells lines compared to unmodified dendrimers. ${ }^{17}$ Therefore, we have chosen a heterobifunctional PEG of MW 2 kDa, orthopyridyl disulfide (OPSS) polyethylene glycol (PEG2000) succinimidyl carboxymethyl ester (OPSS-PEG-SCM), to be conjugated on the surface of DAB dendrimer surface through amide bond to make this delivery system stealthy.

Camptothecin (CPT), a naturally occurring alkaloid, is a potent chemotherapeutic agent with promising preclinical anti-cancer efficacy. ${ }^{18-19}$ Structure-activity studies have shown that the closed lactone ring and the $\mathrm{C}-20-\mathrm{OH}$ group of this highly hydrophobic drug are responsible for cell damage by binding to DNA topoisomerase I through the lactone ring. ${ }^{18-19}$ Its use as anticancer drug is currently limited by its poor aqueous solubility, inactivation of its lactone ring at physiological $\mathrm{pH}$, severe toxicity and rapid blood clearance. ${ }^{18-19}$ To overcome this, the conjugation of CPT using its $20-\mathrm{OH}$ group to a water-soluble nanocarrier was found not only to increase its aqueous solubility, but also to stabilize its lactone ring at physiological $\mathrm{pH} .{ }^{20-23}$ The preparation of such water-soluble polymer-CPT conjugate by converting CPT into an inactive but more stable prodrug able to revert back to the pharmacologically active agent following biological stimuli, resulted in improved drug pharmacokinetics and increased the accumulation of CPT in tumors by the enhanced permeation and retention (EPR) effect. ${ }^{20-24}$ Furthermore, the conjugation of the hydrophobic CPT to any water-soluble polymer led to the formation of varied nanostructures based on hydrophobic-hydrophilic balance. ${ }^{25-28}$

Various self-assembled nanostructures, such as micelles or vesicles, resulting from the conjugation of diverse hydrophobic groups to the surface of dendritic molecules have recently been reported for biomedical applications. ${ }^{29-33}$ Based on this, we planned in this study to synthesize an amphiphilic macromolecule by conjugating a hydrophobic CPT to a hydrophilic PEGylated DAB dendrimer through disulphide linkage (-S-S-), with the hope that it would selfassemble in water due to hydrophobic interactions within the conjugated CPT molecules. The presence of a disulphide linkage in its backbone should make it sensitive to the reducing biothiol glutathione (GSH), , resulting in the destruction of the delivery systems followed by the release of the drug at the desired site of action. ${ }^{34-36}$ The occurrence of GSH was found to be different in intracellular $(\sim 10 \mathrm{mM})$ and extracellular $(<10 \mu \mathrm{M})$ compartments of living cells, and nearly 4- 
fold higher in cancer cells than in normal tissues, making it a particularly interesting stimulus for cancer therapy. ${ }^{34-36}$

In this study, our objectives were therefore (1) to synthesize and characterize CPTanchored PEGylated DAB dendrimer through redox-sensitive disulphide (-S-S-) linkage, (2) to evaluate its self-assembly formation into nanostructures, (3) to assess its redox-responsiveness, (4) to study its DNA condensation ability (5) to assess its cell viability, cellular uptake and transfection efficacy on prostate cancer cells in vitro. 


\section{Experimental}

\subsection{Materials}

Generation 3-diaminobutyric polypropylenimine (DAB) dendrimer was purchased from SyMOChem (Eindhoven, The Netherlands). Orthopyridyl disulfide (OPSS) polyethylene glycol (PEG2000) succinimidyl carboxymethyl ester (OPSS-PEG-SCM) was from JenKem Technology (Plano, TX). Camptothecin (CPT), glutathione (GSH), 3-tritylsulfanylpropionic acid, 4dimethylaminopyridine (DMAP) and N-(3-Dimethylaminopropyl)-N'-ethylcarbodiimide hydrochloride (EDC), Nile Red (NR), Coumarin 153 (C153), Biodialyser (double sided, sample reservoir size $1000 \mu \mathrm{L}$ ), anhydrous dichloromethane (DCM), triethylsilane (TESi), trifluoroacetic acid, diethyl ether, 2,5-dihydroxybenzoic acid (DHB), deuterated solvents DMSO- $\mathrm{d}_{6}, \mathrm{CDCl}_{3}$ and $\mathrm{D}_{2} \mathrm{O}$, were obtained from Sigma Aldrich (Poole, UK). HPLC grade acetonitrile and methanol came from Fisher Scientific (Loughborough, UK). The expression plasmid encoding $\beta$-galactosidase (pCMVsport $\beta$-galactosidase) was from Invitrogen (Paisley, UK) and purified using an Endotoxin-free Giga Plasmid Kit (Qiagen, Hilden, Germany). MilliQ water (with a resistivity of $18.2 \mathrm{M} \Omega . \mathrm{cm}$ at $25^{\circ} \mathrm{C}$ ) was collected using a Milli-Q ${ }^{\circledR}$ Integral water purification system from Merck (Kenilworth, NJ). Tissue culture media and Quanti-iT ${ }^{\circledR}$ PicoGreen ${ }^{\circledR}$ dsDNA reagent was purchased from Life Technologies (Paisley, UK). Vectashield ${ }^{\circledR}$ mounting medium containing propidium iodide(PI) came from Vector Laboratories (Peterborough, UK). Label $\mathrm{IT}^{\circledR}$ Fluorescein and Cy5 Nucleic Acid Labeling Kit were obtained from Cambridge Biosciences (Cambridge, UK). Bioware ${ }^{\circledR}$ androgen-irresponsive PC-3M-luc- C6 human prostate adenocarcinoma cell line able to express the firefly luciferase was purchased from Caliper Life Sciences (Hopkinton, MA).

\subsection{Synthesis of thiolated camptothecin (CPT-SH)}

Thiolated camptothecin (CPT-SH) was synthesized following a method reported by Zhou and colleagues. ${ }^{37}$ Briefly, CPT (40 mg, $0.1148 \mathrm{mmol}$ ), 3-tritylsulfanylpropionic acid (40.01 mg, $0.1148 \mathrm{mmol}$ ), DMAP (24.21 mg, $0.1263 \mathrm{mmol}$ ) and EDC (15.43 mg, $0.1263 \mathrm{mmol}$ ) were mixed in anhydrous DCM $(4 \mathrm{~mL})$. The reaction mixture was stirred overnight at $20{ }^{\circ} \mathrm{C}$ and then filtered using Whatman cellulose filter paper (Diameter: $18.5 \mathrm{~cm}$, Pore Size: $11 \mu \mathrm{m}$ ). The solvent was evaporated from the filtrate and the residue was re-dissolved in $4 \mathrm{~mL}$ of anhydrous DCM, 
followed by the sequential addition of triethylsilane $(0.5 \mathrm{~mL})$ and trifluoroacetic acid $(0.8 \mathrm{~mL})$. The reaction mixture was then stirred for $2 \mathrm{~h}$ at $20{ }^{\circ} \mathrm{C}$ before removal of DCM and TFA by evaporation for $2 \mathrm{~h}$. The residual reaction mixture was redissolved in $500 \mu \mathrm{L}$ DCM and then poured into an excess of cold diethyl ether $(15 \mathrm{~mL})$ to precipitate the final product, a yellow powder which was collected and dried under vacuum in the hood (yield of $88 \%$ ). ${ }^{1} \mathrm{H}-\mathrm{NMR}$ spectra of CPT-SH (1 mg in $0.5 \mathrm{~mL}$ DMSO-d6) was recorded using a Bruker Avance ${ }^{\circledR}$ IIIHD500 NMR spectrometer (Billerica, MA), based on residual proton resonance of the solvent as the internal standard (Figure S1).

\subsection{Synthesis of disulphide-linked camptothecin-bearing PEGylated dendrimer (DAB- PEG-SS-CPT or DPSSC)}

Amine-terminated, generation 3-diaminobutyric polypropyleneimine (DAB) dendrimer was first conjugated to PEG using OPSS-PEG-SCM and then to thiolated camptothecin through disulphide linkage using DMSO as solvent (Figure 1) through in situ two-step reaction. Briefly, DAB (1 equivalent, $60 \mathrm{mg}$ ) was solubilized in $1.5 \mathrm{~mL}$ DMSO for 10 minutes at $20^{\circ} \mathrm{C}$. A freshly prepared solution of OPSS-PEG-SCM (1 equivalent, $81.59 \mathrm{mg}$ ) in $1.5 \mathrm{~mL}$ DMSO was added dropwise to DAB over 10-12 minutes. The light yellow colored reaction mixture was then stirred at $37^{\circ} \mathrm{C}$ for $6 \mathrm{~h}$, protected from light. Thiolated camptothecin (2 equivalents, $31.03 \mathrm{mg}$ in $1.5 \mathrm{~mL}$ DMSO) was then added as a whole to the reaction mixture containing PEGylated DAB. The resulting solution, initially light yellow, gradually became darker and was left stirring at $37{ }^{\circ} \mathrm{C}$, protected from light. After $16 \mathrm{~h}$, the red-brown colored reaction mixture was dialyzed against DMSO $(500 \mathrm{~mL})$ for 2 days, then against methanol $(500 \mathrm{~mL})$ for 2 days and finally dialyzed against distilled water $(2 \mathrm{~L})$ for 2 days at $20^{\circ} \mathrm{C}$, using a dialysis tubing with a molecular weight cut-off of $3.5 \mathrm{kDa}$ to remove the unreacted thiolated CPT, excess PEG and organic solvents respectively. The dialysis medium was changed twice per day. The dialyzed solution was then filtrated with Whatman cellulose filter paper (diameter: $18.5 \mathrm{~cm}$, pore size: $11 \mu \mathrm{m}$ ) and freezedried using a Christ Epsilon 2-4 LSC freeze dryer (Osterode am Harz, Germany). The final product DAB-PEG-SS-CPT or DPSSC, a red colored compound (yield of 59\%), was stored at 0$4{ }^{\circ} \mathrm{C}$ for long-term storage. 1H-NMR spectrum of DPSSC $\left(3.12 \mathrm{mg}\right.$ in $\left.0.5 \mathrm{~mL} \mathrm{CDCl}_{3}\right)$ was 
recorded using Bruker Avance ${ }^{\circledR}$ III-HD500 NMR spectrometer (Billerica, MA) based on residual proton resonance of the solvent as the internal standard.

\subsection{Reverse-phase high performance liquid chromatography (RP-HPLC)}

Phenomenex-Gemini C18 RP-HPLC column (150 x $4.60 \mathrm{~mm})$ was used for reverse-phase HPLC to determine the purity of DPSSC. Milli-Q water containing $0.05 \%$ trifluoroacetic acid (Eluant A) and acetonitrile containing $0.05 \%$ trifluoroacetic acid (Eluant B) were used as solvents to elute the sample. The mobile phase for isocratic elution was run with $25 \%$ Eluant A and $75 \%$ Eluant $B$ at a flow rate of $1 \mathrm{~mL} / \mathrm{min}$ for $10 \mathrm{~min}$. The volume of each injection was $10 \mu \mathrm{L}$, and the detection of the eluted DPSSC sample was performed at $360 \mathrm{~nm}$.

\subsection{Matrix-assisted laser desorption ionization time-of-flight mass spectrometry (MALDI- TOF MS)}

2,5-dihydroxybenzoic acid was used as a matrix to determine the molecular weight of DPSSC and its starting materials DAB and OPSS-PEG-SCM using MALDI-TOF mass spectrometry (Axima CFR, Kratos, Shimadzu, Kyoto, Japan). The sample (10 $\mu \mathrm{L}$ in ultrapure water) was added to the matrix solution (10 $\mu \mathrm{L}, 10 \mathrm{mg} / \mathrm{mL}$ in methanol) in $1: 1$ (v:v) ratio and mixed. The mixture solution $(1 \mu \mathrm{L})$ was placed on a MALDI sample plate. All the spots were dried before measurement and the instrument was first calibrated with four standards and operated in a linear mode with a $\mathrm{N}_{2}$ laser operating at $337 \mathrm{~nm}$ to generate the ions, which were then accelerated to 20 $\mathrm{kV}$. Mass spectra of DPSSC and its starting materials mainly exhibited singly charged molecular ions $[\mathrm{M}]^{+}$with their fragmented products.

\subsection{Fluorescence spectra of DPSSC and CPT in DMSO}

Fluorescence spectra of DPSSC and CPT solutions in DMSO were recorded with a Varian Cary Eclipse Fluorescence spectrophotometer (Palo Alto, CA) $\left(\lambda_{\text {exc }}: 365 \mathrm{~nm}, \lambda_{\text {em }}: 375-700 \mathrm{~nm}\right.$, excitation and emission slits at $5 \mathrm{~nm}$ ). All the solutions were incubated for $2 \mathrm{~h}$ before fluorescence measurement. 


\subsection{Entrapment of Nile Red within DPSSC}

The ability of DPSSC to self-assemble was evaluated by steady-state fluorescence technique using hydrophobic fluorescence probe Nile Red. Nile Red stock solution $\left(16 \mu \mathrm{L}, 3.14 \times 10^{-3} \mathrm{M}\right.$, $0.98 \mathrm{mg}$ in $0.98 \mathrm{~mL}$ methanol) was added to $5-\mathrm{mL}$ plastic vials. Following complete evaporation of the methanol after 5-6 h, $1 \mathrm{~mL}$ DPSSC dendrimer solutions prepared at concentrations ranging from 0.05 to $3500 \mu \mathrm{g} / \mathrm{mL}$ in PBS ( $\mathrm{pH} 7.4$ ), was added to the vials, making the final probe concentration $50 \mu \mathrm{M}$. Each sample was vigorously vortexed for 5 minutes and then incubated for $24 \mathrm{~h}$ at $25{ }^{\circ} \mathrm{C}$, protected from light. Nile Red fluorescence spectrum was recorded for each sample with a Varian Cary Eclipse Fluorescence spectrophotometer (Palo Alto, CA) ( $\lambda_{\text {exc }}: 600$ $\mathrm{nm}, \lambda_{\text {em }}: 620-800 \mathrm{~nm}$, excitation and emission slits at $10 \mathrm{~nm}$ and $20 \mathrm{~nm}$ respectively).

\subsection{Fluorescence spectra of DPSSC in phosphate buffer (pH 7.4)}

Fluorescence spectra of DPSSC at different concentrations $(0.2,0.5 .1 .0$ and $2.0 \mathrm{mg} / \mathrm{mL})$ in phosphate buffer $(\mathrm{pH}$ 7.4) were recorded with a Varian Cary Eclipse Fluorescence spectrophotometer (Palo Alto, CA) ( $\lambda_{\text {exc }}: 365 \mathrm{~nm}, \lambda_{\mathrm{em}}: 375-700 \mathrm{~nm}$, excitation and emission slits at $5 \mathrm{~nm}$ ). All the solutions were incubated for $24 \mathrm{~h}$ before fluorescence measurement.

\subsection{Transmission electron microscope (TEM)}

The morphology of DPSSC-based nanostructures at various concentrations (200, 1000 and 2000 $\mu \mathrm{g} / \mathrm{mL}$ in PBS $\mathrm{pH}$ 7.4) was determined using a JEOL JEM-1200EX transmission electron microscope (Jeol, Tokyo, Japan) operating at an accelerating voltage of $80 \mathrm{kV}$. After a minimum 24-h incubation, sample solution ( $3 \mu \mathrm{L})$ was drop-cast on a carbon-coated copper grid (400 mesh size), dried in a desiccator overnight, before imaging.

\subsection{Hydrodynamic size and zeta potential of self-assembling DPSSC}

Dynamic light scattering (DLS) was used to measure the hydrodynamic diameter $\left(\mathrm{d}_{\mathrm{H}}\right)$ and the zeta potential of DPSSC (200 to $2000 \mu \mathrm{g} / \mathrm{mL}$ ) in PBS (pH 7.4) at $37^{\circ} \mathrm{C}$, with a Malvern NanoZS (Malvern Instruments, Malvern, UK). He-Ne laser $(\lambda=632.8 \mathrm{~nm}, 4 \mathrm{~mW})$ was used as a source and scattering photons were collected at $173^{\circ}$ scattering angle. 
The stability of DPSSC in presence of foetal bovine serum (FBS) was also assessed by measuring the size of DPSSC $(2000 \mu \mathrm{g} / \mathrm{mL})$ in complete medium containing $10 \%$ (FBS) at various time intervals.

\subsection{Micropolarity of DPSSC self-aggregates}

Micropolarity of DPSSC self-aggregates was measured using a hydrophobic fluorescent probe, coumarin-153 (C153). A stock solution of C153 (1.0 $\times 10^{-3} \mathrm{M}, 3.19 \mathrm{mg}$ in $10 \mathrm{~mL}$ methanol) was prepared and $2 \mu \mathrm{L}$ of this solution was added to $5-\mathrm{mL}$ plastic vials. Following complete evaporation of the methanol after 5-6 h, $1 \mathrm{~mL}$ DPSSC prepared at various concentrations $(0,0.2$, $0.5,1$ and $2 \mathrm{mg} / \mathrm{mL}$ in PBS pH 7.4) was added to the vials, making the final probe concentration $2 \times 10^{-6} \mathrm{M}$. Each sample solution was vigorously vortexed for 5 minutes and then incubated for $24 \mathrm{~h}$ at $25^{\circ} \mathrm{C}$, protected from light, before measurement. The fluorescence emission spectrum of C153 probe in aqueous phosphate buffer ( $\mathrm{pH} 7.4$ ), was recorded in the presence of DPSSC at various concentrations ( $\lambda_{\text {exc }}: 420 \mathrm{~nm}, \lambda_{\mathrm{em}}: 430-700 \mathrm{~nm}$, excitation and emission slits at $5 \mathrm{~nm}$ and $10 \mathrm{~nm}$ respectively), using a Varian Cary Eclipse Fluorescence spectrophotometer (Palo Alto, CA). The frequency of C153 fluorescence emission was used to calculate the micropolarity of the microenvironment of the aggregates, which is expressed by $\pi^{*}$-polarity scale, as follows:

$\bar{v}_{e m}=21.217-3.505 \pi^{*}$

where, $\bar{v}_{e m}\left[\right.$ in $\left.10^{3} \mathrm{~cm}^{-1}\right]$ is the wavenumber corresponding to the emission maximum of C153.

\subsection{Circular Dichroism (CD) spectroscopy}

Chirascan V100 (Applied Photophysics, Leatherhead, Surrey, UK) with a 150W air-cooled Xenon arc lamp was used to record CD spectra (190-700 nm), using a $10 \mathrm{~mm}$ path length quartz UV- Vis absorption cell (Hellma Analytics, Müllheim, Germany). Dendrimer solutions (2 $\mathrm{mg} / \mathrm{mL}$ in DMSO and phosphate buffer $\mathrm{pH}$ 7.4) were prepared and incubated overnight before measurement at $25{ }^{\circ} \mathrm{C}$. Background spectra of the different solvents (DMSO and phosphate buffer) were acquired, then subtracted from the sample spectra and smoothed before plotting. 


\subsection{Redox-sensitive CPT release}

The redox-triggered release of CPT from DPSSC was assessed using glutathione, a biological reducing agent. DPSSC $(5 \mathrm{mg} / \mathrm{mL})$ and glutathione solutions $(100 \mathrm{mM}$ and $100 \mu \mathrm{M})$ were prepared in phosphate buffer ( $\mathrm{pH}$ 7.4). Samples of DPSSC $(1 \mathrm{mg} / \mathrm{mL})$ in presence or absence of various glutathione concentrations $(0,10 \mu \mathrm{M}, 10 \mathrm{mM}$ and $50 \mathrm{mM})$ were prepared as follows:

(i) No GSH: $200 \mu \mathrm{L}$ of DPSSC ( $5 \mathrm{mg} / \mathrm{mL}$ ) with $800 \mu \mathrm{L}$ buffer (pH 7.4)

(ii) $10 \mu \mathrm{M}$ GSH: $200 \mu \mathrm{L}$ of DPSSC $(5 \mathrm{mg} / \mathrm{mL})$ with $700 \mu \mathrm{L}$ buffer $(\mathrm{pH} 7.4)$ and $100 \mu \mathrm{L}$ glutathione solution $(100 \mu \mathrm{M})$

(iii) $10 \mathrm{mM} \mathrm{GSH}: 200 \mu \mathrm{L}$ of DPSSC $(5 \mathrm{mg} / \mathrm{mL})$ with $700 \mu \mathrm{L}$ buffer (pH 7.4) and $100 \mu \mathrm{L}$ glutathione solution $(100 \mathrm{mM})$

(iv) $50 \mathrm{mM}$ GSH: $200 \mu \mathrm{L}$ of DPSSC $(5 \mathrm{mg} / \mathrm{mL})$ with $300 \mu \mathrm{L}$ buffer $(\mathrm{pH} 7.4)$ and $500 \mu \mathrm{L}$ glutathione solution $(100 \mathrm{mM})$.

Two sides of the biodialyser were closed using 3500 MWCO dialysis bag. Each biodialyser containing DPSSC with various GSH concentrations $(0,10 \mu \mathrm{M}, 10 \mathrm{mM}$ and $50 \mathrm{mM})$ was then immersed in $60 \mathrm{~mL}$ of phosphate buffer (pH 7.4) having the same GSH concentration as inside the biodialyser. The samples were then incubated in the dark under stirring condition $(100 \mathrm{rpm})$ at $37{ }^{\circ} \mathrm{C}$ for 7 days. Release of the CPT was measured by taking out $1 \mathrm{~mL}$ aliquot from the release media and replacing with $1 \mathrm{~mL}$ of fresh media at different time intervals. Each measurement was repeated in triplicates. An absorbance based calibration curve of CPT in phosphate buffer $(\mathrm{pH}$ 7.4) was prepared to calculate the concentration of released CPT from DPSSC at different time intervals.

\subsection{Redox-sensitive change of size and zeta potential of DPSSC dendrimersomes}

The hydrodynamic diameter and zeta potential of DPSSC in phosphate buffer (pH 7.4) incubated with glutathione were measured at various time intervals over 7 days at $37{ }^{\circ} \mathrm{C}$ by dynamic light scattering (DLS), using a Malvern Nano ZS instrument (He-Ne laser, $\lambda=632.8 \mathrm{~nm}, 4 \mathrm{~mW}, 173^{\circ}$ scattering angle, Malvern Instruments, Malvern, UK) (Figures S10 and Table S2). Samples of DPSSC $(1.2 \mathrm{~mL}, 1 \mathrm{mg} / \mathrm{mL})$ in presence or absence of various glutathione concentrations $(0,10$ $\mu \mathrm{M}, 10 \mathrm{mM}$ and $50 \mathrm{mM}$ ) were prepared as follows: 
(i) No GSH: $240 \mu \mathrm{L}$ of DPSSC (5 mg/mL) with $960 \mu \mathrm{L}$ buffer $(\mathrm{pH} 7.4)$

(ii) $10 \mu \mathrm{M}$ GSH: $240 \mu \mathrm{L}$ of DPSSC $(5 \mathrm{mg} / \mathrm{mL})$ with $840 \mu \mathrm{L}$ buffer $(\mathrm{pH} 7.4)$ and $120 \mu \mathrm{L}$ GSH solution $(100 \mu \mathrm{M})$

(iii) 10 mM GSH: $240 \mu \mathrm{L}$ of DPSSC ( $5 \mathrm{mg} / \mathrm{mL}$ ) with $840 \mu \mathrm{L}$ buffer (pH 7.4) and $120 \mu \mathrm{L}$ GSH solution $(100 \mathrm{mM})$

(iv) 50 mM GSH: $240 \mu \mathrm{L}$ of DPSSC ( $5 \mathrm{mg} / \mathrm{mL})$ with $360 \mu \mathrm{L}$ buffer (pH 7.4) and $600 \mu \mathrm{L}$ GSH solution $(100 \mathrm{mM})$

\subsection{Evaluation of DNA condensation}

\subsubsection{PicoGreen assay}

PicoGreen ${ }^{\circledR}$ assay was performed according to the supplier's protocol to assess the ability of DPSSC to complex the negatively charged plasmid DNA encoding $\beta$-galactosidase at various dendrimer: DNA weight ratios $(20: 1,10: 1,5: 1,2: 1,1: 1,0.5: 1$ and 0:1) in Tris-EDTA (TE) buffer (10 mM Tris, $1 \mathrm{mM}$ EDTA, pH 7.5). DNA solution (500 $\mu \mathrm{L}, 10 \mu \mathrm{g} / \mathrm{mL}$ in TE buffer) was added to each dendrimer solution $(500 \mu \mathrm{L}$ in TE buffer) and vortexed to prepare $1 \mathrm{~mL}$ complex at various weight ratios. PicoGreen ${ }^{\circledR}$ reagent was then diluted (200-fold in TE buffer) on the day of the experiment, and one $\mathrm{mL}$ PicoGreen ${ }^{\circledR}$ solution was added to the TE buffer with or without complexes and vortexed immediately before the first measurement. The fluorescence emission intensity of PicoGreen ${ }^{\circledR}\left(\lambda_{\text {exc }}: 480 \mathrm{~nm}, \lambda_{\text {em }}: 520 \mathrm{~nm}\right.$, excitation and emission slits: $5 \mathrm{~nm}$ each) in

presence of the DPSSC complexes was measured at various time intervals using a Varian Cary Eclipse Fluorescence spectrophotometer (Palo Alto, CA). Results were represented as percentage of DNA condensation.

Fluorescence emission spectra of PicoGreen ${ }^{\circledR}\left(\lambda_{\text {exc }}\right.$ : $480 \mathrm{~nm}, \lambda_{\text {em }}: 490-700 \mathrm{~nm}$, excitation and emission slits: 5 and $5 \mathrm{~nm}$ ) and DPSSC ( $\lambda_{\text {exc }}: 365 \mathrm{~nm}, \lambda_{\text {em }}: 375-700 \mathrm{~nm}$, excitation and emission slits: 5 and $10 \mathrm{~nm}$ ) were recorded using a Varian Cary Eclipse Fluorescence spectrophotometer (Palo Alto, CA).

Fluorescence spectra of PicoGreen and DPSSC showed no change in emission maximum in dendriplexes in comparison to their native spectra, confirming that there was no physical interference between the conjugated CPT and complexed DNA. 


\subsubsection{Gel retardation assay}

DNA condensation ability of DPSSC was also tested using a gel retardation assay at dendrimer: DNA weight ratios 20:1, 10:1, 5:1, 2:1, 1:1, 0.5:1 and 0:1, in TE buffer (10 mM Tris, $1 \mathrm{mM}$ EDTA, $\mathrm{pH}$ 7.5), with a fixed final DNA concentration $(20 \mu \mathrm{g} / \mathrm{mL})$. Uncomplexed DPSSC, equivalent to 10:1 and 20:1 dendrimer: DNA weight ratios, were also run as controls to rule out any interference from DPSSC. Each sample solution $(10 \mu \mathrm{L})$ was mixed with loading buffer (2 $\mu \mathrm{L}$, Bioline, UK), before being loaded on a 1X Tris-Borate-EDTA (TBE) ( $89 \mathrm{mM}$ Tris base, 89 $\mathrm{mM}$ boric acid, $2 \mathrm{mM} \mathrm{Na} 2$-EDTA, $\mathrm{pH} 8.3$ ) buffered $0.8 \%(\mathrm{w} / \mathrm{v})$ agarose gel containing ethidium bromide $(0.4 \mu \mathrm{g} / \mathrm{mL})$, with $1 \mathrm{x}$ TBE as a running buffer. The HyperLadder $1 \mathrm{~Kb}$ (Bioline, UK) was used as a DNA size marker and the gel was run at $50 \mathrm{~V}$ for $1 \mathrm{~h}$ before being photographed under UV light.

\subsection{Size and zeta potential measurement of DPSSC -DNA complexes}

Hydrodynamic diameter and zeta potential of DPSSC-DNA complexes at various dendrimer: DNA weight ratios (0.5:1, 1:1, 2:1, 5:1, 10:1 and 20:1) was assessed using Malvern NanoZS instrument (Malvern Instruments, Malvern, UK) immediately after mixing a fixed amount of DNA $(50 \mu \mathrm{g})$ to dendrimer solutions in PBS ( $\mathrm{pH} 7.4)$.

\subsection{Morphology of DPSSC -DNA complexes}

The morphology of DPSSC-DNA complexes was observed using JEOL JEM-1200EX transmission electron microscope (Jeol, Tokyo, Japan) operating at an accelerating voltage of 80 $\mathrm{kV}$. A fixed amount of DNA (50 $\mu \mathrm{g})$ was mixed with DPSSC in PBS (pH 7.4) at dendrimer: DNA weight ratios of 5:1 and 10:1, before being drop-cast ( $3 \mu \mathrm{L}$ of each complex) on a carboncoated copper grid (400 mesh size), then kept in a desiccator overnight for drying before imaging.

\subsection{Cell culture}

Minimum Essential Medium (MEM), supplemented with 10\% (v/v) fetal bovine serum, 1\% (v/v) L-glutamine and $0.5 \%(\mathrm{v} / \mathrm{v})$ penicillin-streptomycin was used as medium to culture monolayers 
of human prostate adenocarcinoma PC3-Luc cells at $37{ }^{\circ} \mathrm{C}$ in a $5 \%$ carbon dioxide humid atmosphere.

\subsection{Cell viability measurement}

PC3-Luc cells were seeded at a density of 5000 cells per well in 96-well plates in MEM medium and left to grow at $37^{\circ} \mathrm{C}$ for $24 \mathrm{~h}$ in a $5 \%$ carbon dioxide, humid atmosphere to assess the cell viability using a standard MTT assay. After $24 \mathrm{~h}$, the medium was removed and cells were then treated with various concentrations of DPSSC, CPT and DAB (in CPT equivalent concentrations). After treatment for 24,48 and $72 \mathrm{~h}, 50 \mu \mathrm{L}$ of MTT solution $(5 \mathrm{mg} / \mathrm{mL}$ in PBS $\mathrm{pH}$ 7.4) was added in each well and the cells were incubated for $4 \mathrm{~h}$ at $37{ }^{\circ} \mathrm{C}$. Following the removal of the medium, the formazan dye produced during the reduction of MTT by the living cells, was solubilized by adding $200 \mu \mathrm{L}$ DMSO in each well. The plates were kept at $37{ }^{\circ} \mathrm{C}$ in incubator for $30 \mathrm{~min}$ to solubilize formazan dye completely before being measured at $540 \mathrm{~nm}$ with a Multiskan Ascent ${ }^{\circledR}$ plate reader (Thermo Scientific, Waltham, MA).

\subsection{Cellular uptake of dendriplex}

\subsection{Qualitative analysis}

The cellular uptake of DPSSC complexed to DNA was qualitatively assessed using confocal microscopy. Plasmid DNA was labeled with the fluorescent probe Cy5 using a Label IT ${ }^{\circledR}$ Cy5 Nucleic Acid Labeling kit, as described by the manufacturer. PC3-Luc cells were seeded on coverslips in 6-well plates at a concentration of $2 \times 10^{5}$ cells per well in $3 \mathrm{~mL}$ MEM media, and left to grow at $37^{\circ} \mathrm{C}$. After $24 \mathrm{~h}$, the medium was removed and the cells were then treated with Cy5-labelled DNA (2.5 $\mu \mathrm{g} /$ well) complexed to DPSSC, at various dendrimer: DNA weight ratios (5:1, 10:1 and 20:1). Cells were treated with DAB dendriplex (dendrimer: DNA weight ratio of 5:1) and DNA solution as positive and negative controls, along with untreated cells. After 2 hours of incubation at $37{ }^{\circ} \mathrm{C}$, the cells were then washed twice with $2 \mathrm{~mL}$ phosphate buffered saline (pH 7.4) before being fixed with $2 \mathrm{~mL}$ methanol for $10 \mathrm{~min}$ at $20^{\circ} \mathrm{C}$. Methanol was then removed and the nuclei of the cells were then stained with Vectashield ${ }^{\circledR}$ mounting medium containing propidium iodide (PI). Treated cells were examined using a Leica TCS SP5 confocal 
microscope (Wetzlar, Germany). Nuclear staining agent PI was excited with the $543 \mathrm{~nm}$ laser line (emission bandwidth: 597-647 nm), Cy5 (which labeled the DNA) was excited with the 633 $\mathrm{nm}$ laser line (emission bandwidth: 663-709 nm). CPT was excited with the 405nm UV laser line (emission bandwidth: 400-480 nm).

\subsubsection{Quantitative analysis}

Cellular uptake of DPSSC complexed to DNA was quantified using flow cytometry. Plasmid DNA was labeled with the fluorescent probe FITC using a Label IT $^{\circledR}$ FITC Nucleic Acid Labeling kit, as described by the manufacturer. PC3-Luc cells were seeded at a density of $2 \times 10^{5}$ cells per well in 6-well plates, and left to grow at $37^{\circ} \mathrm{C}$. After $24 \mathrm{~h}$, the medium was removed and the cells were treated with fluorescein-labeled DNA (2.5 $\mu \mathrm{g}$ DNA/well) complexed with DPSSC at dendrimer: DNA weight ratios 5:1, 10:1 and 20:1. Cells were treated with DAB dendriplex (dendrimer: DNA weight ratio of 5:1) and DNA solution as positive and negative controls, along with untreated cells. After $2 \mathrm{~h}$ incubation with the treatments, the medium was removed and washed with $2 \mathrm{~mL}$ PBS (pH 7.4) three times and finally single cell suspensions were prepared once the cells have detached after addition of $250 \mu \mathrm{L}$ trypsin followed by $500 \mu \mathrm{L}$ medium per well. FACSCanto ${ }^{\circledR}$ flow cytometer (BD, Franklin Lakes, NJ) was used to quantify the cellular uptake analyzing mean fluorescence intensity by FACSDiva ${ }^{\circledR}$ software (BD, Franklin Lakes, NJ), counting ten thousand cells (gated events) for each sample.

\subsection{Gene transfection}

Gene transfection of DPSSC complexed to plasmid DNA encoding Green Fluorescent Protein (GFP) was carried out by flow cytometry on PC3-Luc cell line. The cells were seeded at a density of $1 \times 10^{5}$ cells per well in 6-well plates and let to grow at $37^{\circ} \mathrm{C}$. After $24 \mathrm{~h}$, the medium was removed and the cells were treated with DNA (10 $\mu \mathrm{g}$ DNA/well) complexed with DPSSC at various dendrimer: DNA weight ratios (5:1, 10:1 and 20:1). Cells were also treated with DAB dendriplex (dendrimer: DNA weight ratio of 5:1) and DNA solution as positive and negative controls, along with untreated cells. After $24 \mathrm{~h}$ incubation with the treatments, the medium was removed, but the cells were not washed with PBS. Single cell suspensions were prepared once the cells have detached after addition of $250 \mu \mathrm{L}$ trypsin followed by $500 \mu \mathrm{L}$ medium per well. 
FACSCanto ${ }^{\circledR}$ flow cytometer (BD, Franklin Lakes, NJ) was used to quantify the cellular uptake analyzing mean fluorescence intensity by FACSDiva ${ }^{\circledR}$ software (BD, Franklin Lakes, NJ), counting ten thousand cells (gated events) for each sample.

\subsection{Statistical analysis}

Results were expressed as means \pm standard error of the mean. One-way analysis of variance and Tukey multiple comparison post-test (Minitab ${ }^{\circledR}$ software, State College, PE) was used to assess the statistical significance. Differences were considered statistically significant for P values lower than 0.05 . 


\section{Results and discussion}

3.1. Synthesis and characterization of the disulfide-linked camptothecin-bearing PEGylated dendrimer

Disulfide-linked camptothecin bearing PEGylated dendrimers DAB-PEG-SS-CPT (DPSSC) was synthesized using a two-step in situ reaction (Figure 1). 

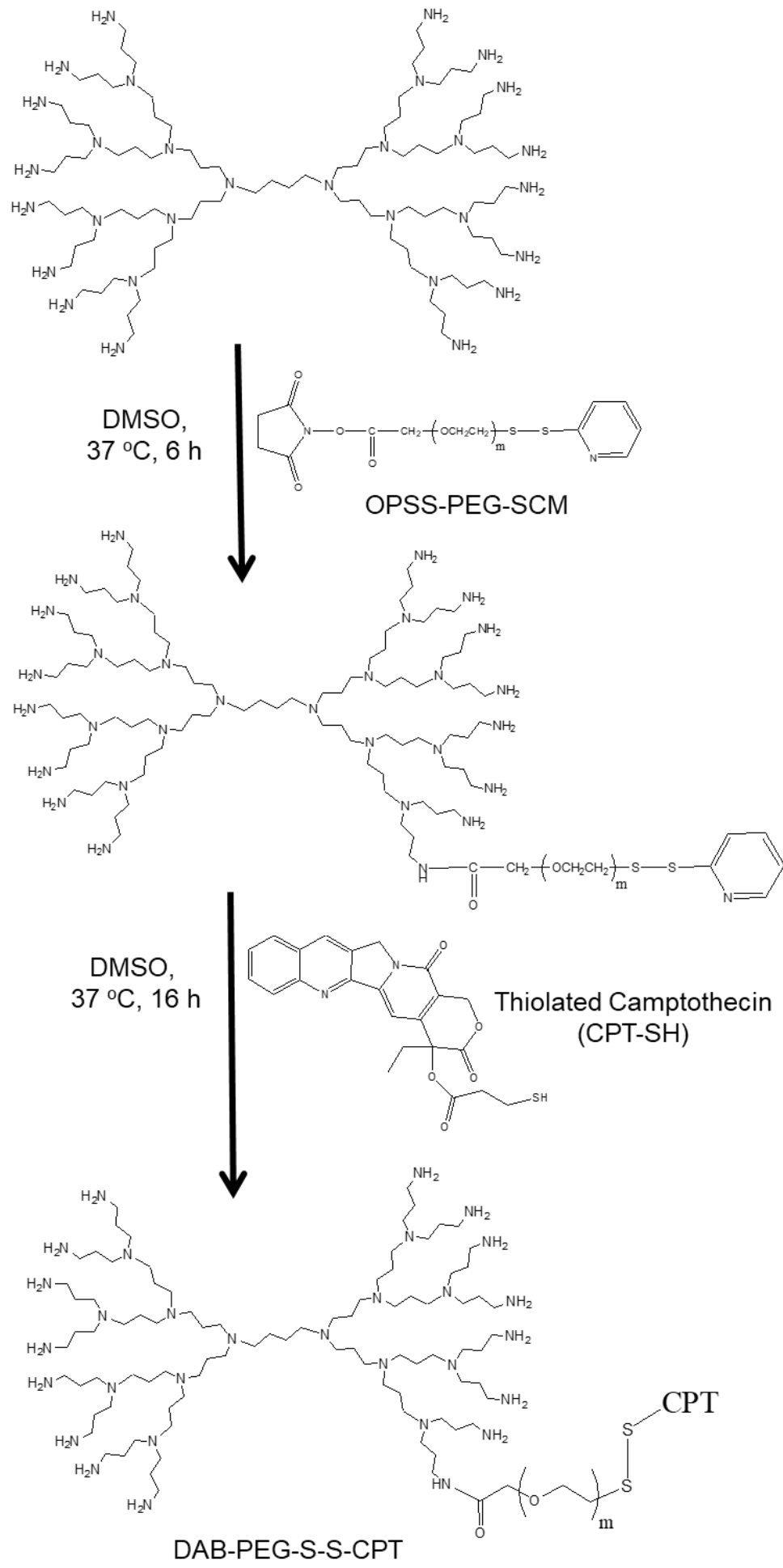

Figure 1. General synthetic scheme for DAB-PEG-SS-CPT or DPSSC, where $\mathrm{m}=45$. 
The synthesis of DPSSC was confirmed by FTIR, ${ }^{1} \mathrm{H}-\mathrm{NMR}$, and MALDI-TOF MS. Infrared (ATR) spectrum of DPSSC showed the presence of a new peak at $1647 \mathrm{~cm}^{-1}$ (corresponding to an amide bond) and the absence of a peak at $1719-1740 \mathrm{~cm}^{-1}$ (corresponding to the succinimidyl carboxymethyl ester group of the OPSS-PEG-SCM), in comparison to starting materials (Figure S2), thus indicating the successful conjugation of PEG to DAB through an amide bond.

The conjugation of CPT and PEG to DAB was confirmed by ${ }^{1} \mathrm{H}-\mathrm{NMR}$, as follows: ${ }^{1} \mathrm{H}-\mathrm{NMR}$ (600 MHz, $\left.\mathrm{CDCl}_{3}\right): \delta 2.38-2.47$ ppm, DAB ( $\left.\mathrm{NCH}_{2}-\mathrm{CH}_{2}-\mathbf{C H}_{2}-\mathrm{N}\right)$ (a); $83.84-3.91$ ppm, PEG (NHCO- $\left.\mathbf{C H}_{2}-\mathrm{OCH}_{2} \mathrm{CH}_{2}\right)$ (b); $\delta 5.23-5.25$ ppm, CPT (CH-CH-N-CO) (c); $\delta 5.67-5.70$ ppm, CPT (CHCH-O) (d) (Figure S3).

The purity of DPSSC, free from any thiolated CPT, was demonstrated by HPLC (Figure S4). The average molecular weight of DPSSC $(\mathrm{m} / z=4480 \mathrm{Da})$ was determined by MALDI- TOF mass spectrometry (Figure S5), indicating that the ratio of conjugated PEG as well as CPT per dendrimer was nearly 1. CPT loading in DPSSC was found to be $7.75 \mathrm{wt} \%$ based on MALDITOF mass spectrometry (Section S1). The conjugation of CPT to the dendrimer did not inactivate the drug: the fluorescence spectrum of DPSSC in DMSO showed an emission maximum in the $430 \mathrm{~nm}$ region, consistent with the presence of CPT having a closed lactone ring (Figure 2A) rather than the inactive open carboxylate which emits at $446 \mathrm{~nm}^{25}$ 

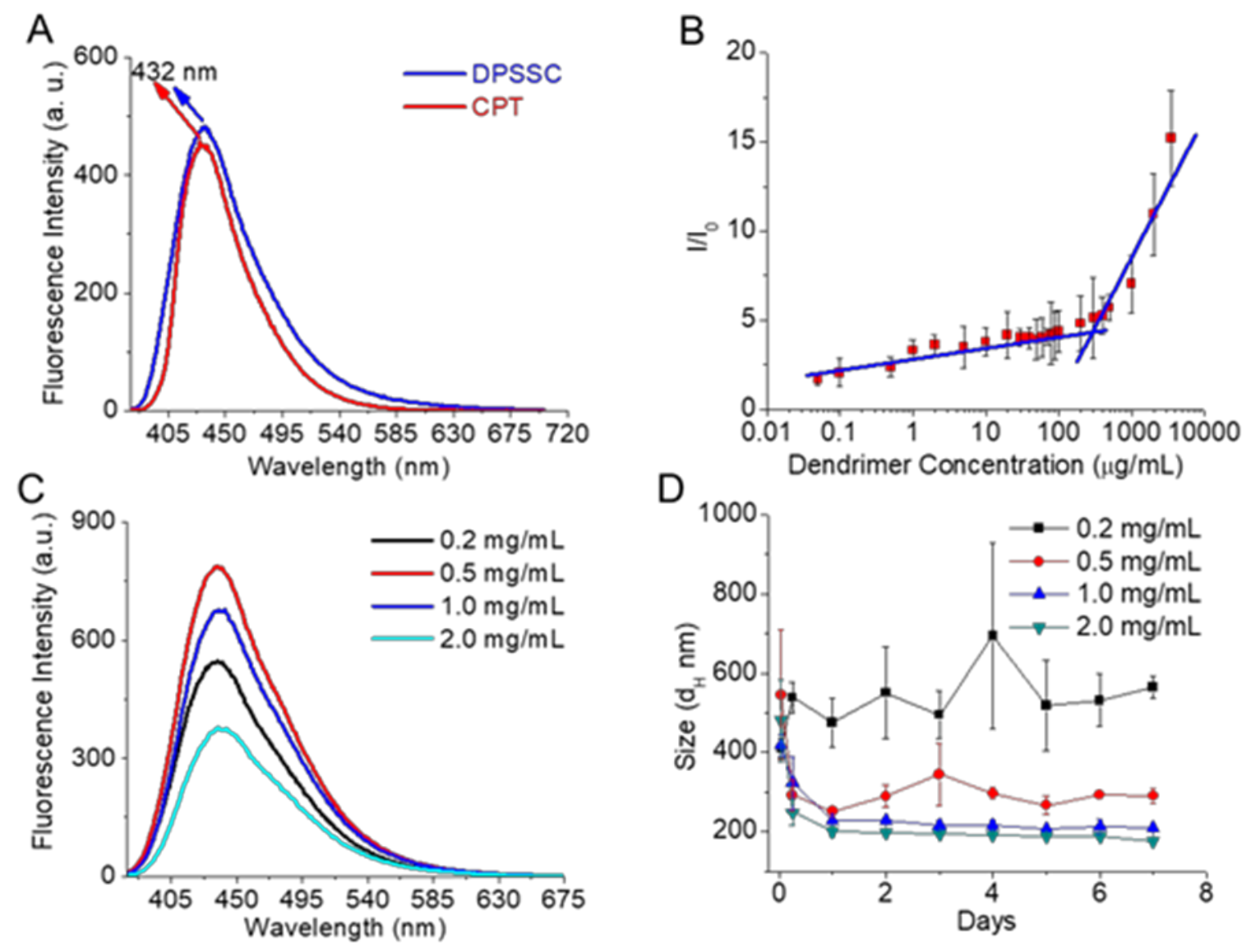

Figure 2. (A) Fluorescence emission spectra $\left(\lambda_{\text {exc }}=365 \mathrm{~nm}\right)$ of DPSSC and CPT in DMSO. (B) Relative fluorescence intensity $\left(\mathrm{I} / \mathrm{I}_{0}\right)$ of Nile Red versus DPSSC concentrations. (C) Fluorescence spectra $\left(\lambda_{\mathrm{exc}}=365 \mathrm{~nm}\right)$ of DPSSC solutions ( $\mathrm{pH}$ 7.4). (D) Hydrodynamic size of DPSSC solutions ( $\mathrm{pH} 7.4)$ at $37^{\circ} \mathrm{C}$ with time $(\mathrm{n}=3)$.

\subsection{Evaluation of the self-assembly formation of dendrimer}

Self-assembly of amphiphilic DPSSC dendrimers in phosphate buffer ( $\mathrm{pH} 7.4$ ) was studied by steady-state fluorescence technique using Nile Red (NR) as the probe molecule. NR, a highly hydrophobic fluorescent probe, is weakly fluorescent in water, but it shows fluorescence intensity when it is being solubilized in a nonpolar medium or within the hydrophobic region of any self-assembled aggregate. ${ }^{33}$ Self-assembly formation of DPSSC was confirmed by a gradual rise of fluorescence intensity of Nile Red with increasing dendrimer concentrations in PBS (pH 7.4) (Figures S6). The critical aggregation concentration (CAC) $(\sim 200 \mu \mathrm{g} / \mathrm{mL})$ was calculated 
from the inflection point of the plot of relative fluorescence intensities of NR at various dendrimer concentrations (Figure 2B). DPSSC dendrimer was still able to undergo selfassembly, even with its low hydrophobicity content at $\mathrm{pH}$ 7.4. The fluorescence emission intensity of DPSSC above the CAC did not increase linearly with increasing DPSSC concentrations, but instead exhibited a sharp decrease from $1 \mathrm{mg} / \mathrm{mL}$ (Figure 2C). This decrease in emission intensity was attributed to the static quenching caused by the closer proximity of the CPT molecules with increasing DPSSC concentrations, further confirming the self-assembly of DPSSC. ${ }^{20,26}$

\subsection{Hydrodynamic size and zeta potential of dendrimer self-assembled nanostructures}

The hydrodynamic size of DPSSC nanostructures $(0.5,1$ and $2 \mathrm{mg} / \mathrm{mL})$ incubated at $37{ }^{\circ} \mathrm{C}$ sharply decreased with time and became steady after $12 \mathrm{~h}$ at around $250-300 \mathrm{~nm}$ (for $0.5 \mathrm{mg} / \mathrm{mL}$ ) and 150-200 $\mathrm{nm}$ (for 1 and $2 \mathrm{mg} / \mathrm{mL}$ ) (Figure 2D). This decrease might be explained by the

formation of more stable and compact nanostructures at higher concentrations, resulting from increased hydrophobic interactions among CPT molecules of DPSSC at higher concentrations supporting the fluorescence quenching results (Figure 2C). In contrary, at comparatively lower concentration $(0.2 \mathrm{mg} / \mathrm{mL})$, near CAC, DPSSC did not show any decrease in hydrodynamic size with time, indicating a less compact nature of the aggregates. In addition, the size of DPSSC was even smaller $(\sim 100 \mathrm{~nm})$ in presence of complete medium containing $10 \%$ FBS. It was stable over time (ranging from $109 \pm 4 \mathrm{~nm}$ to $105 \pm 1 \mathrm{~nm}$ following $1 \mathrm{~h}$ and $24 \mathrm{~h}$ incubation with the medium) at $37{ }^{\circ} \mathrm{C}$ (Figure S7). The size of DPSSC nanostructures in presence or absence of FBS was below the cut-off size for extravasation, which is $400 \mathrm{~nm}$ for most tumors. ${ }^{38}$

DPSSC nanostructures $(0.5-2 \mathrm{mg} / \mathrm{mL})$ were bearing a positive zeta potential comprised between 3 and $5 \mathrm{mV}$ for up to 7 days (Table 1). This would increase their electrostatic interactions with the negatively charged cellular membranes, which is favorable to an enhanced cellular uptake of the delivery system. ${ }^{39}$ 
Table 1. Zeta potential of self-assembled DPSSC nanostructures in phosphate buffer ( $\mathrm{pH} 7.4)$ after $6 \mathrm{~h}$ and 7 days of incubation at $37^{\circ} \mathrm{C}(\mathrm{n}=3)$.

\begin{tabular}{ccc}
\hline \multirow{2}{*}{$\begin{array}{c}\text { DPSSC solutions } \\
(\mathbf{m g} / \mathbf{m L})\end{array}$} & \multicolumn{2}{c}{ Zeta Potential $(\mathbf{m V})$} \\
\cline { 2 - 3 } & After $\mathbf{6} \mathbf{h}$ & After $\mathbf{7}$ days \\
\hline $\mathbf{0 . 2}$ & $0.95 \pm 0.22$ & $-0.13 \pm 0.23$ \\
$\mathbf{0 . 5}$ & $3.32 \pm 0.18$ & $3.59 \pm 0.59$ \\
$\mathbf{1}$ & $4.21 \pm 0.65$ & $4.97 \pm 0.49$ \\
$\mathbf{2}$ & $4.38 \pm 0.39$ & $4.85 \pm 0.81$ \\
\hline
\end{tabular}

\subsection{Formation of dendrimer-based vesicles}

TEM images of DPSSC revealed that DPSSC dendrimer assembled into unilamellar, spherical-shaped vesicles (dendrimersomes) with a size lower than $100 \mathrm{~nm}$ (Figure 3). TEM images also showed that DPSSC started forming vesicles at comparatively lower concentrations close to the CAC value, but the vesicles became more regular-shaped with increasing concentrations of dendrimer, supporting the formation of more compact aggregates at higher concentrations. The size of dendrimersomes obtained from the TEM images was found to be smaller than that observed with DLS, as TEM imaging technique involves drying of the samples before measurement, unlike hydrodynamic size measurement through DLS. 

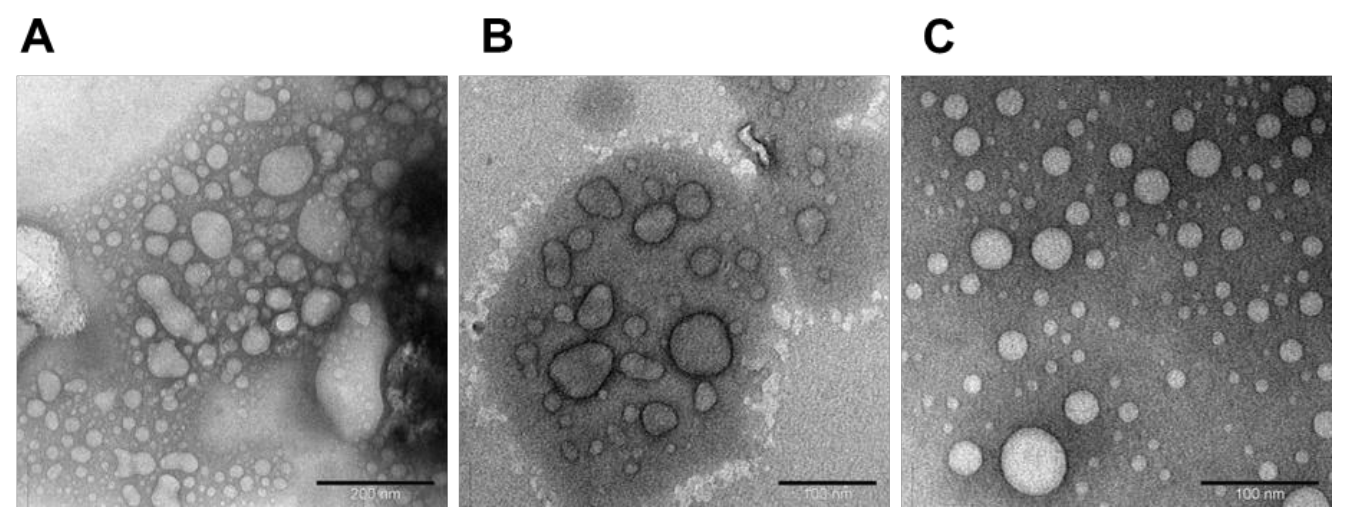

Figure 3. TEM images of DPSSC solution ( $\mathrm{pH} \mathrm{7.4)} \mathrm{at} \mathrm{various} \mathrm{concentrations:} 0.2 \mathrm{mg} / \mathrm{mL}(\mathrm{A})$, $1.0 \mathrm{mg} / \mathrm{mL}(\mathrm{B})$ and $2.0 \mathrm{mg} / \mathrm{mL}(\mathrm{C})$ (scale bar: $100 \mathrm{~nm}$ ).

\subsection{Micropolarity of dendrimer-based vesicles}

The steady-state fluorescence spectrum of coumarin-153 (C153) in presence of DPSSC showed a steady increase of fluorescence intensity of emission maximum (Figure 4A), suggesting an increasing hydrophobicity of the microenvironment of dendrimersomes. The appearance of a shoulder band at $\sim 490 \mathrm{~nm}$ was observed from $0.5 \mathrm{mg} / \mathrm{mL}$ dendrimer solution. The intensity of this shoulder band gradually increased with DPSSC concentrations and a characteristic blue shift of emission maximum of C153 was observed for $2 \mathrm{mg} / \mathrm{mL}$ DPSSC in comparison to its low concentration counterpart. The appearance of the shoulder band indicated a distribution of C153 at multiple locations in vesicular assemblies, similar to other steroidal skeleton-based vesicular structure. ${ }^{40}$ The blue shift of the emission maximum $\left(\lambda_{\max }=494 \mathrm{~nm}\right)$ of C153 solubilized within DPSSC $(2 \mathrm{mg} / \mathrm{mL})$ predicted the micropolarity $\left(\pi^{*}\right.$-value $\left.=0.278\right)$ of the hydrophobic microenvironment of bilayer, which is similar to the polarity of hexafluorobenzene (0.27). ${ }^{41}$ This therefore confirmed that the vesicular bilayer was composed of the aromatic benzene rings of CPT. 


\section{A}

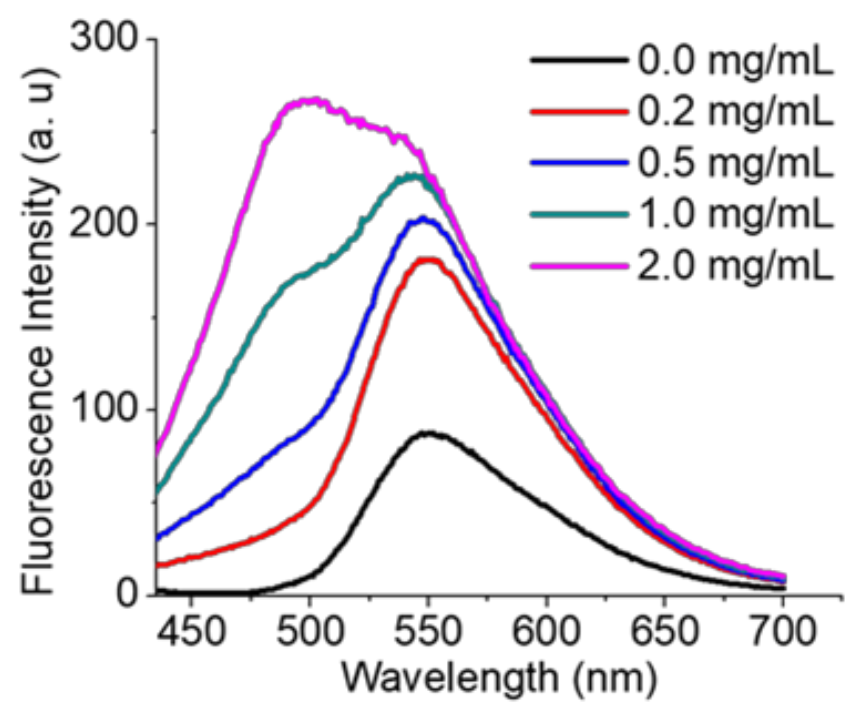

B

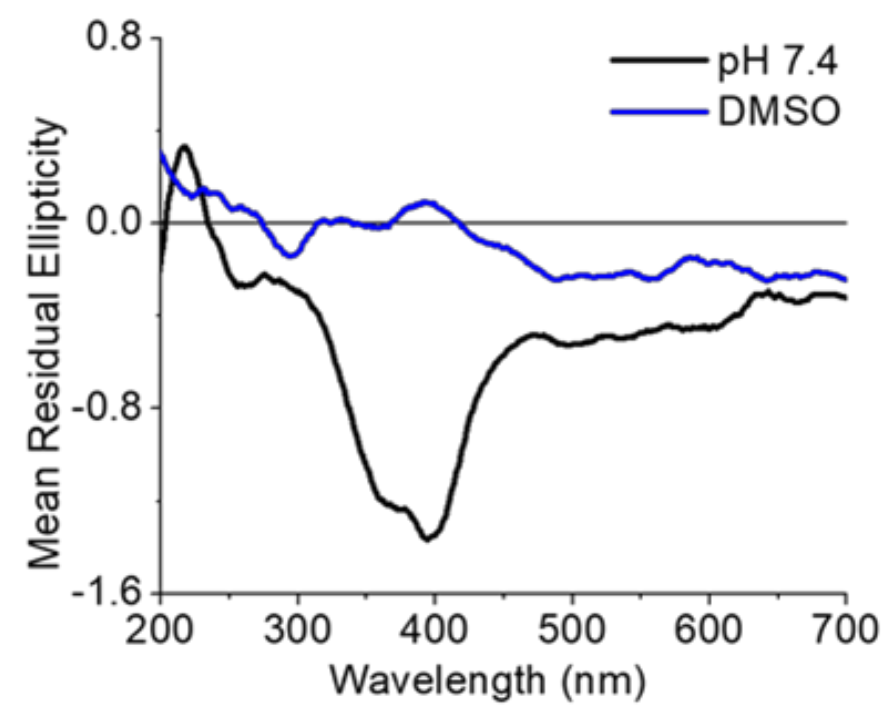

Figure 4. (A) Fluorescence spectra of C153 ( $\lambda_{\text {exc }}: 420 \mathrm{~nm}, \lambda_{\mathrm{em}}$ : $430-700 \mathrm{~nm}$ ) in presence and absence of DPSSC solutions (pH 7.4). (B) CD spectra of DPSSC solution $(2 \mathrm{mg} / \mathrm{mL})$ in various solvents. 


\subsection{CPT Packing within dendrimer-based vesicles}

To investigate the CPT packing within the vesicles, circular dichroism (CD) spectra of DPSSC ( $2 \mathrm{mg} / \mathrm{mL}$ ) in phosphate buffer ( $\mathrm{pH} 7.4$ ) and DMSO was recorded. DPSSC displayed distinctive CD signals in the CPT absorption regions between 330 and $400 \mathrm{~nm}$ in buffer, whereas no CD signal was obtained for DPSSC dissolved in DMSO, where the DPSSC dendrimers are expected to exist in a monomeric form (Figure 4B) ${ }^{25}$ As CD measures absorption differences between left and right circularly polarized light, these results suggest a chiral packing of the CPT moieties in the vesicles with negative chirality and left-handed helical arrangement.

\subsection{Evaluation of redox sensitivity of dendrimer-based vesicles}

In presence of glutathione, the vesicle bilayers are expected to disassemble, with a concomitant

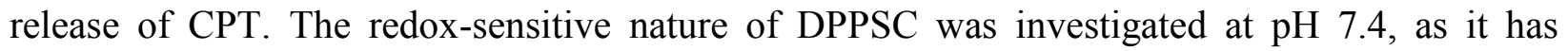
previously been reported that thiol-disulfide exchange reactions could occur under mild or neutral conditions with quantitative or near-quantitative yields, unlike that observed in acidic conditions. ${ }^{42}$ CPT release from DPSSC vesicles was found to be minimal (about 10 to $15 \%$ ) in non-redox condition, as well as in presence of $10 \mu \mathrm{M}$ GSH (equivalent to the extracellular concentration in normal cells) (Figure 5). This might be explained by the absence of disruption of dendrimersomes at this GSH concentration, which is supported by the stability of vesicle size (around $100 \mathrm{~nm}$ ) and zeta potential (around $5 \mathrm{mV}$ ) at these experimental conditions (Figure S8 and Table S1). In presence of $10 \mathrm{mM} \mathrm{GSH}$ (equivalent to the intracellular concentration in normal cells), the CPT release increased to about 30-35\% within 7 days (Figure 5), due to the breakage of disulphide bonds, resulting in the formation of less compact, larger sized vesicles with lower zeta potential (Figure S8 and Table S1). The CPT release sharply increased with time to about $70 \%$, in presence of $50 \mathrm{mM}$ glutathione (equivalent to the intracellular environment of tumor tissue), responsible for a further disintegration of dendrimersomes and generation of smaller sized, nearly disintegrated aggregates $(\sim 10 \mathrm{~nm})$ bearing a more positive zeta potential $(\sim 23 \mathrm{mV})$. The sustained, high release of CPT in tumor-relevant reductive conditions therefore confirmed the potential of dendrimersomes for cancer therapy. 


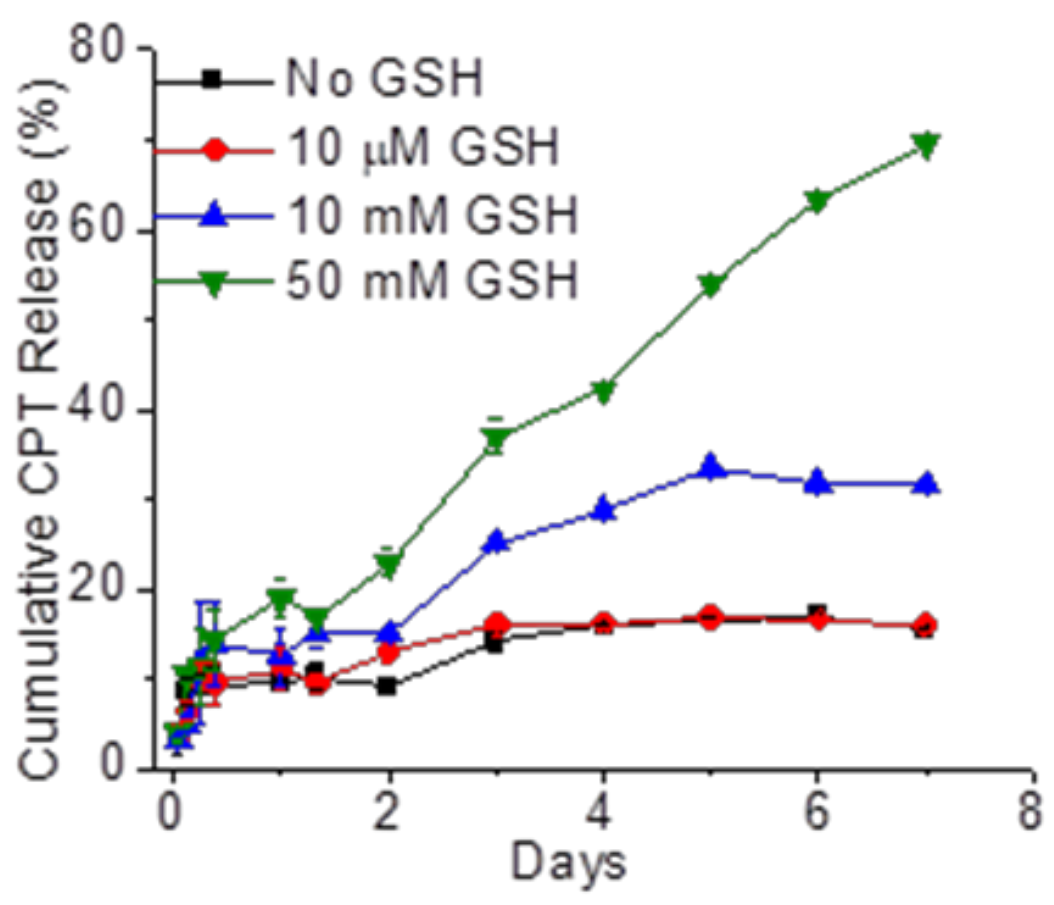

Figure 5. Cumulative CPT release (\%) from DPSSC solution ( $1 \mathrm{mg} / \mathrm{mL}$, phosphate buffer, $\mathrm{pH}$ 7.4) with time in presence and absence of $\mathrm{GSH}$ at $37^{\circ} \mathrm{C}(\mathrm{n}=3)$.

\subsection{Characterization of dendriplex formation}

3.8.1. Evaluation of DNA condensation. The protonated primary amines of the CPT-bearing PEGylated dendrimer can efficiently bind to negatively charged phosphodiester groups of DNA through electrostatic interactions leading to the formation of dendrimer: DNA complexes (dendriplexes). PicoGreen ${ }^{\circledR}$, an intercalating fluorochrome, selectively binds double-stranded DNA followed by a significantly increased fluorescence intensity. In contrary, successful dendriplex formation between the negatively charged dsDNA and positively charged dendrimer through electrostatic interactions can knockout PicoGreen ${ }^{\circledR}$ from the DNA groove, resulting in a decrease in the fluorescence intensity of the PicoGreen ${ }^{\circledR}$. Figure 6A showed a gradual reduction of fluorescence intensity of PicoGreen ${ }^{\circledR}$ with increasing DPSSC: DNA ratio, confirming DNA condensing ability of DPSSC vesicles. PicoGreen ${ }^{\circledR}$ assay also demonstrated that DPSSC 
dendrimersomes condensed more than $85 \%$ of the DNA at dendrimer: DNA weight ratios of 5:1 and higher (Figure 6B). DNA condensation occurred instantly and was found to be stable for at least $24 \mathrm{~h}$ (Figures 6B). Furthermore, the fluorescence emission of DPSSC or conjugated CPT in pro-drug dendrimer, in presence and absence of DNA, did not show any change in spectral pattern confirming no interference from CPT on DNA condensation (Figure S9).

These results from PicoGreen ${ }^{\circledR}$ assay were also confirmed by a gel retardation assay. Figure 6C showed also a complete DNA condensing ability of DPSSC at dendrimer: DNA weight ratios of 5:1 and higher. The absence of bands from two uncomplexed DPSSC, at two equivalent concentrations (10:1 and 20:1) and same exposure level, also ruled out any possibility of interference from the conjugated CPT. 

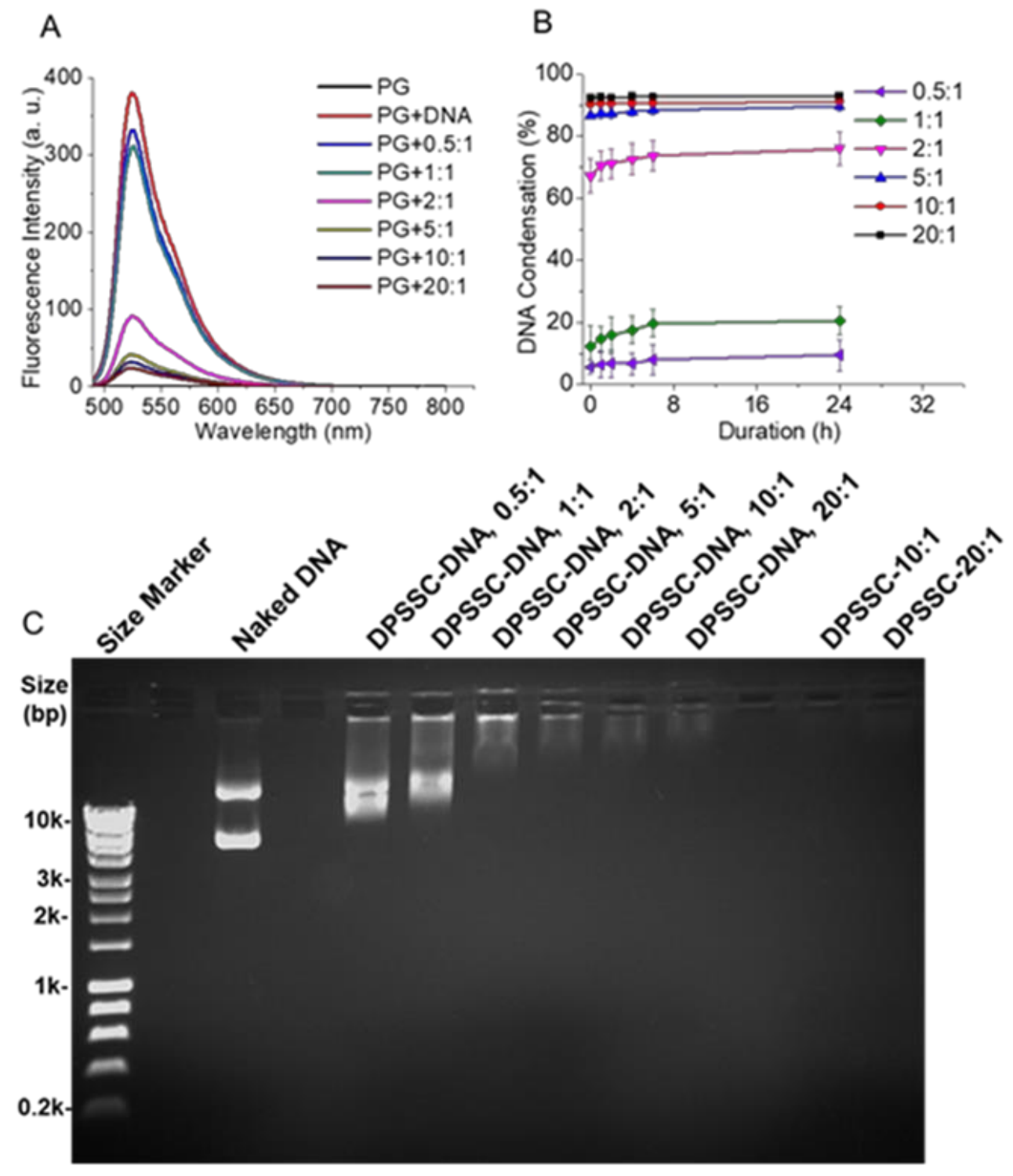

Figure 6. (A) Fluorescence emission spectra $\left(\lambda_{\text {exc }}: 480 \mathrm{~nm}\right)$ of PicoGreen (PG) in presence of dendriplexes at DPSSC: DNA weight ratios of 0.5:1, 1:1, 2:1, 5:1, 10:1 and 20:1 (control: PG in presence and absence of DNA). The amount of DNA was fixed at $10 \mu \mathrm{g}$ for each complex. (B) DNA condensation ability of DPSSC-based dendriplexes using PicoGreen ${ }^{\circledR}$ assay with time at various dendrimer: DNA weight ratios $(\mathrm{n}=4)$; (C) Gel retardation assay of DPSSC-DNA complexes at various dendrimer: DNA weight ratios (0.5:1, 1:1, 2:1, 5:1, 10:1,20:1) (controls: uncomplexed DPSSC at two equivalent concentrations (10:1 and 20:1), DNA only). The amount of DNA was fixed at $20 \mu \mathrm{g}$ for each complex. 
3.8.2. Size, charge and shape of dendriplex. DPSSC dendriplexes showed a decrease in size with increasing dendrimer: DNA ratios, to reach an average size lower than $150 \mathrm{~nm}$ at dendrimer: DNA ratios of 5:1 and higher, with a low polydispersity index (0.15 to 0.3) (Figure 7A). The reduction in size of dendriplexes, at dendrimer: DNA ratios of 5:1 and higher, might be attributed to the complete condensing ability of DPSSC from that weight ratio as evidenced by PicoGreen ${ }^{\circledR}$ and gel retardation assay. Their smaller size may facilitate their extravasation to cancer cells more easily than for larger, unmodified DAB dendriplexes (average size of $196 \mathrm{~nm}$, polydispersity index: 0.683). ${ }^{10}$ These complexes displayed an increase in zeta potential with increasing dendrimer: DNA ratios, to reach a slightly positive surface charge $(0.5 \mathrm{mV})$ at dendrimer: DNA ratios higher than 5:1 (Figure 7A). DPSSC has retained its ability to form vesicles of sizes less than $100 \mathrm{~nm}$ even after complexation with DNA, as demonstrated by TEM imaging (Figure 7B).
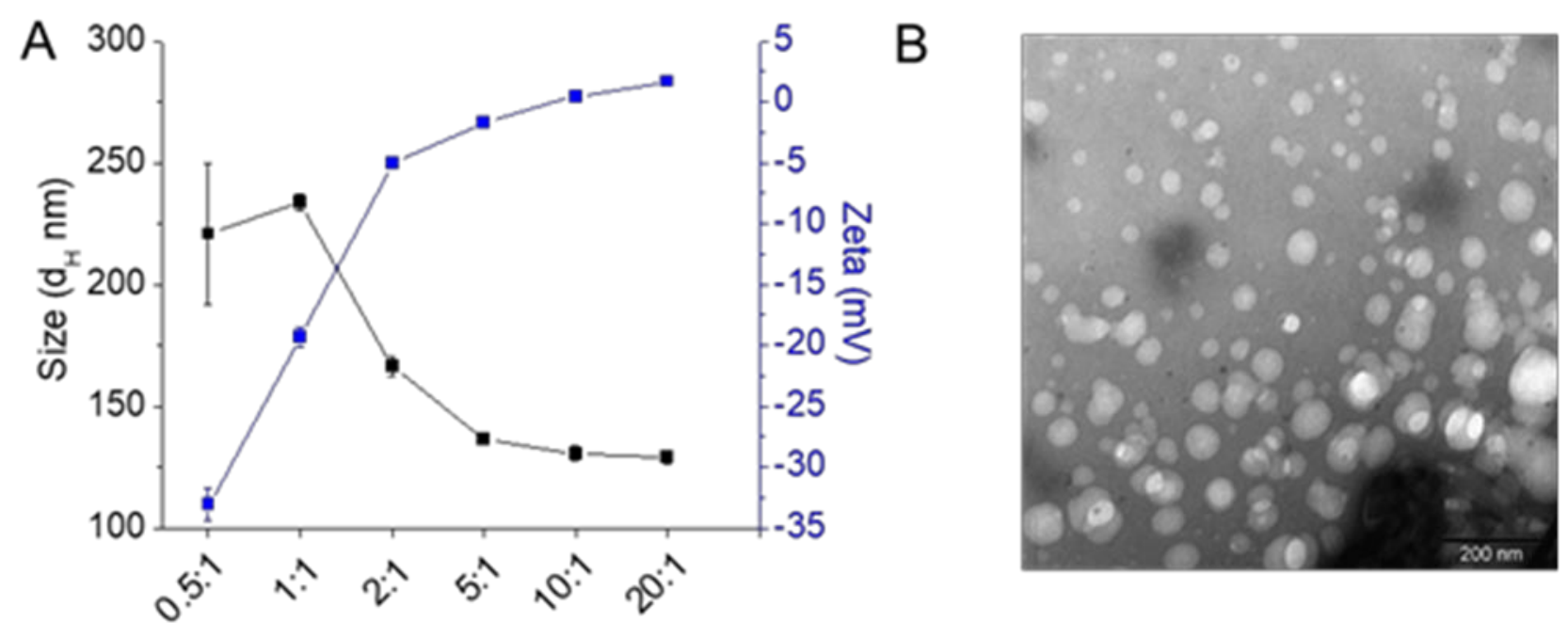

Figure 7. (A) Size and zeta potential of DPSSC-based dendriplexes $(\mathrm{pH} 7.4)$ at various dendrimer: DNA weight ratios at $37^{\circ} \mathrm{C}(\mathrm{n}=3)$; (B) TEM image of DPSSC-based dendriplex at 10:1 weight ratio. 


\subsection{In vitro analysis}

3.9.1. Evaluation of cell viability. The cell viability following treatment with DPSSC dendrimersomes was evaluated by a MTT assay on PC-3M-Luc prostate adenocarcinoma cell line. Treatment of the cells with DPSSC dendrimersomes resulted in a higher cell viability than for DAB or free CPT after 24, 48 and $72 \mathrm{~h}$ (Table 2, Figure S10). This might be explained by the slow release of CPT from the stable, self-aggregated pro-drug dendrimer and the PEGylation of the dendrimersomes. ${ }^{17}$

Table 2. Viability of PC3-Luc cells, expressed as $\mathrm{IC}_{50}$ values, following treatment with DPSSC dendrimersomes for 24, 48 and $72 \mathrm{~h}$ (controls: DAB and CPT) $(\mathrm{n}=15)$.

\begin{tabular}{cccc}
\hline \multirow{2}{*}{ Time (h) } & \multicolumn{3}{c}{$\mathbf{I C}_{50}(\boldsymbol{\mu g} / \mathbf{m L})(\mathbf{m e a n} \pm$ S.E.M.) } \\
\cline { 2 - 4 } & DPSSC & DAB & Free CPT \\
\hline $\mathbf{2 4}$ & $11.46 \pm 0.97$ & $7.06 \pm 0.63$ & $0.08 \pm 0.03$ \\
$\mathbf{4 8}$ & $9.84 \pm 0.48$ & $6.27 \pm 0.86$ & $0.15 \pm 0.05$ \\
$\mathbf{7 2}$ & $8.61 \pm 0.98$ & $5.49 \pm 0.58$ & $0.17 \pm 0.07$ \\
\hline
\end{tabular}

\subsubsection{Cellular uptake of dendriplexes.}

3.9.2.1. Qualitative analysis. The ability of DPSSC dendrimersomes complexed with fluorescently labelled Cy5-DNA to be taken up by PC-3M-Luc cancer cells following $2 \mathrm{~h}$ incubation was assessed by confocal microscopy. Confocal microscopy (Figure 8) confirmed the cellular uptake of complexed Cy5-DNA (green fluorescence) and conjugated CPT (blue fluorescence) carried by the dendrimersomes, which appeared to be higher than that observed with DAB dendriplex (dendrimer: DNA ratio: 5:1). CPT uptake appeared to be highest after treatment with the dendrimersomes at a ratio of 20:1 among all three tested ratios, unlike DNA uptake which was similar for the 3 ratios. Both CPT and DNA were found to be co-localized in the nuclei of the cells. 


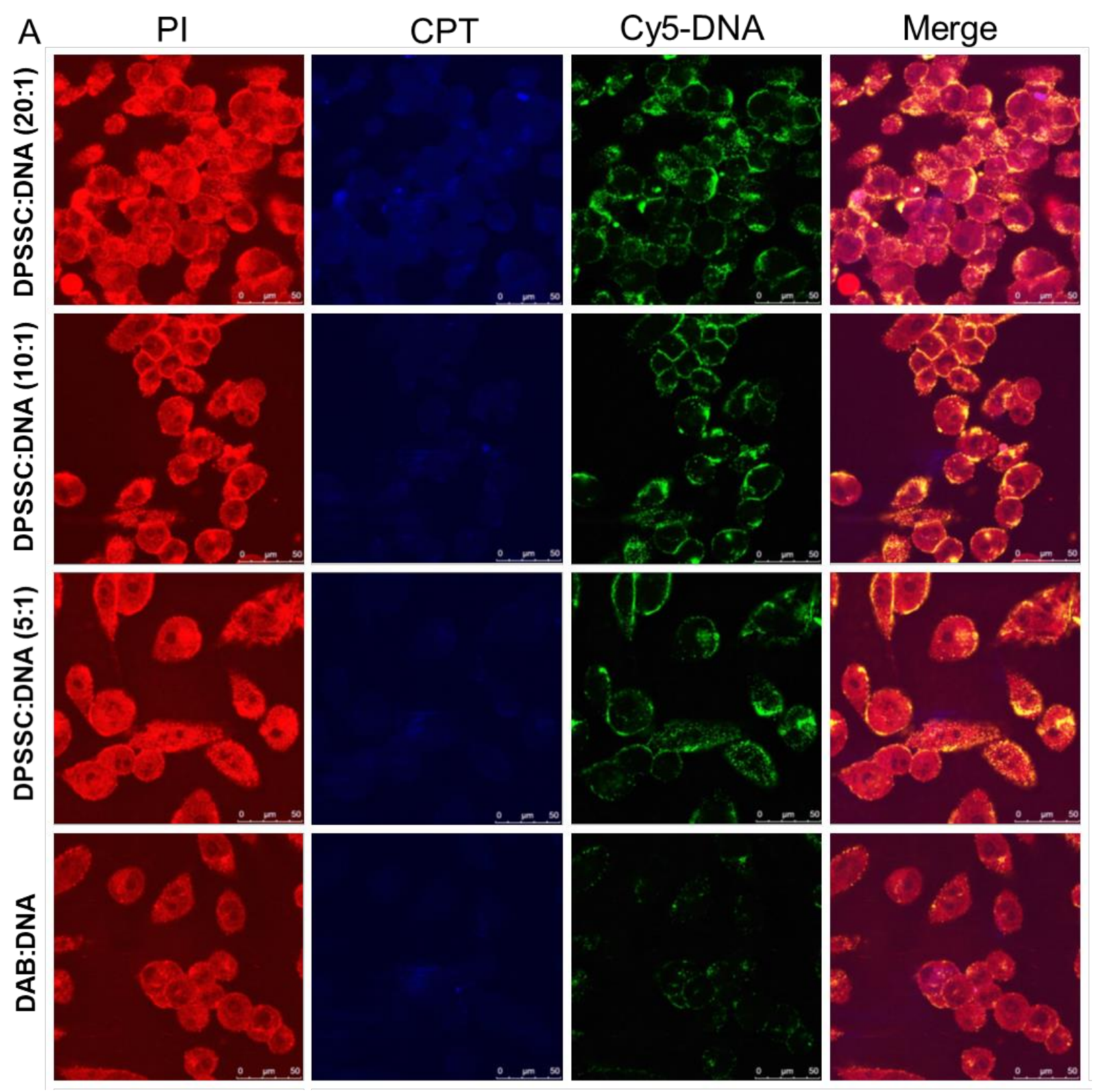

Figure 8. Confocal microscopy images of the cellular uptake of Cy5-labelled DNA (2.5 $\mu \mathrm{g} /$ well), complexed with DPSSC at various weight ratios (control: DAB: DNA) (magnification: $\mathrm{x} 40$ ). 
3.9.2.2. Quantitative analysis. This DNA cellular uptake was quantitatively confirmed by flow cytometry (Figures 9A and S11). The highest cellular fluorescence of fluorescein-labelled DNA was observed at a dendrimer: DNA ratio of 5:1 (mean fluorescence intensity (MFI) of 4123 \pm 45 arbitrary units (a.u.)), which was respectively 1.6-fold and 16.3-fold higher than that observed after treatment with DAB dendriplex (2524 \pm 139 a.u.) and DNA solution (252 \pm 2 a.u.). High cellular uptake was also obtained at ratios of 10:1 (3826 \pm 49 a.u.) and 20:1 (3717 \pm 65 a.u.). 
A

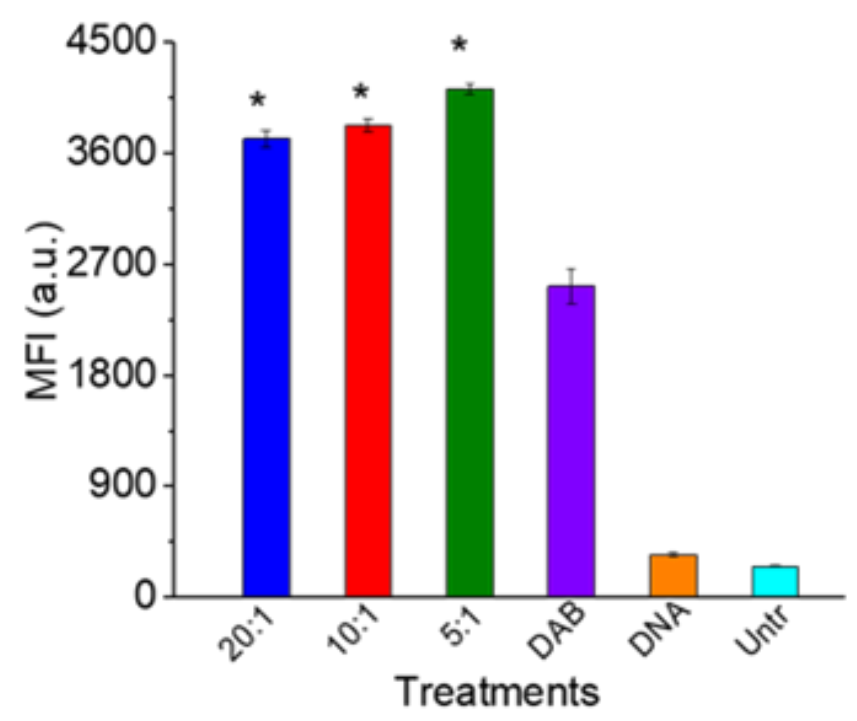

B

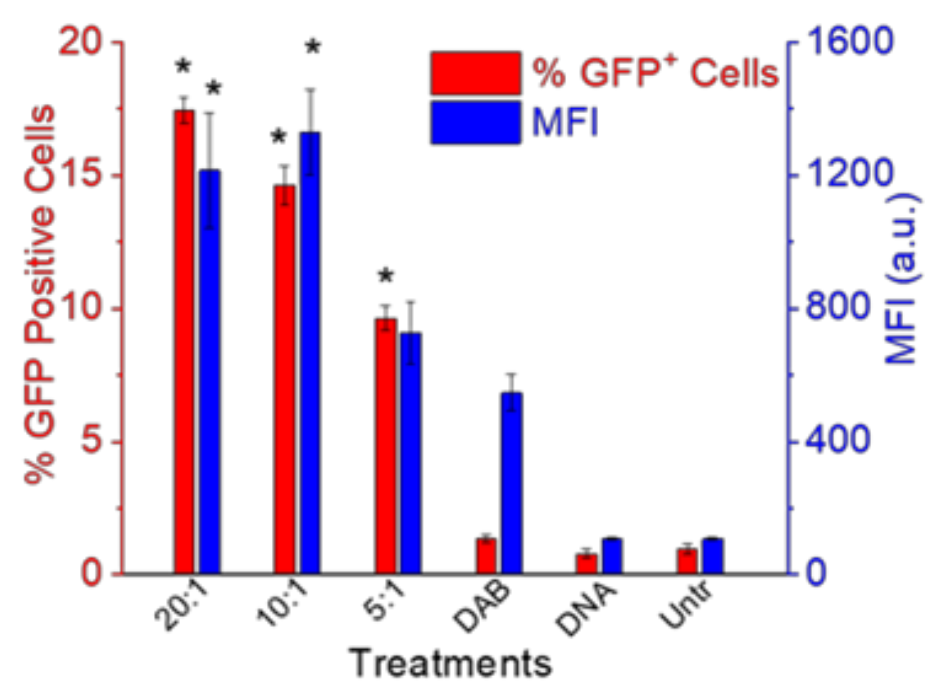

Figure 9. (A) Quantification of the cellular uptake of fluorescein-labelled DNA (2.5 $\mu \mathrm{g} / \mathrm{well})$ complexed with DPSSC, by PC3-Luc cells (controls: DAB-DNA, DNA solution) (n=3) (*: P $<0.05$ compared with DAB-DNA). (B) Transfection efficacy of DPSSC complexed with DNA encoding GFP (10 $\mu \mathrm{g} /$ well) on PC3-Luc cells (controls: DAB-DNA (5:1 ratio), DNA solution) (*: $\mathrm{P}<0.05$ compared with DAB-DNA). 


\subsubsection{Evaluation of gene expression of DPSSC dendrimersomes complexed with DNA.}

DPSSC dendrimersomes complexed with DNA were able to increase the cellular uptake and transfection level of DNA (Figure 9B). The dendrimersomes complexed with DNA encoding green fluorescent protein (GFP) at dendrimer: DNA ratios of 20:1, 10:1 and 5:1 led to higher gene transfection than with DAB dendriplex by respectively 2.2 -fold, 2.4-fold and 1.3-fold following $24 \mathrm{~h}$ incubation. The percentage of GFP-positive cells followed a similar pattern, with $17.4 \pm 0.4 \%, 14.6 \pm 0.7 \%$ and $9.6 \pm 0.4 \%$ of cells being GFP-positive following incubation with complexes at ratios of 20:1, 10:1 and 5:1. By contrast, only $1.3 \pm 0.1 \%$ of cells were GFPpositive following treatment with DAB dendriplex.

To the best of our knowledge, this is the first report on CPT-bearing PEGylated polypropylenimine dendrimer forming spontaneous, redox-sensitive, stable cationic vesicles (dendrimersomes), with an additional capability to carry DNA leading to enhanced gene expression in prostate cancer cells. Other CPT-modified various polymers, including dendrimers, have previously been reported but only as drug delivery carriers. ${ }^{43-45}$ Earlier report on redoxresponsive pro-drug delivery system from CPT-bearing linear dendritic molecules showed a comparatively burst release, but in presence of intracellular redox condition (10 mM DTT) of normal cells, unfavorable due to its non-tumor-specific nature. ${ }^{46}$ Self-assembled nanostructures were also reported from amphiphilic polypropylenimine dendrimers, but without exhibiting any redox-sensitive release of drug and gene transfection. ${ }^{47}$ Prior reports on redox-responsive PAMAM to deliver either DNA or hydrophobic drugs were unable to show the formation of any vesicles and possibility of co-delivery of drugs and nucleic acids. ${ }^{48-49}$ This current study demonstrated that the pro-drug dendrimer DPSSC can be used as a single carrier for dual delivery of drug and DNA to cancer cells, which makes it a much more promising carrier than a mixture of delivery systems each carrying a single therapeutic agent. ${ }^{50}$

\section{Conclusion}

In this proof-of-concept study, a disulfide-linked CPT-bearing PEGylated dendrimer has been successfully synthesized through in situ two-step reactions. To our knowledge, this is the first report of CPT-conjugated PEGylated dendrimer able to spontaneously self-assemble into cationic vesicles $(\sim 3-5 \mathrm{mV})$ (dendrimersomes) that were stable over 7 days. The bilayer of these 
dendrimersomes were made of hydrophobic CPT molecules with negative chirality and lefthanded helical arrangement of the drug. The dendrimersomes were also able to entrap an additional guest inside their nanostructure, indicating their capability to carry another encapsulated chemotherapeutic drug in addition to CPT. They were able to release about $70 \%$ of the conjugated camptothecin in presence of $50 \mathrm{mM}$ glutathione (equivalent to the intracellular environment of tumor tissue), in a sustained manner and with a gradual breakage of their nanostructures. Furthermore, CPT-bearing PEGylated dendrimer was able to form positively charged $(\sim 0.5-2 \mathrm{mV})$, smaller-sized (less than $150 \mathrm{~nm})$ and stable complexes with plasmid DNA, condensing more than $85 \%$ of the DNA at dendrimer: DNA weight ratios of 5:1 and higher. These dendriplexes led to an enhanced cellular uptake of DNA (by up to 1.6-fold) and increased gene transfection (by up to 2.4-fold) in prostate cancer cells in comparison with that of the highly efficacious unmodified DAB dendrimer. We believe this strategy could be extended to the synthesis of other supramolecular nanostructures for dual delivery of anti-cancer drugs and nucleic acids, with the aim of potentially getting synergistic therapeutic effects on cancer cells. This disulfide-linked CPT-bearing PEGylated dendrimer formulation has the potential to be further tailored to respond to a variety of delivery hurdles encountered in cancer treatment, ultimately optimizing the therapeutic efficacy of its cargo. This novel dendrimersome therefore holds promising prospects for the redox-triggered combination delivery of anti-cancer drugs and nucleic acids for cancer therapy.

\section{Conflicts of interest}

There are no conflicts to declare.

\section{Acknowledgements}

This work was financially supported by a grant from Worldwide Cancer Research [grant number 16-1303] to C.D. and H.Y.L. P.L. and S.S. are respectively funded by research grants from Worldwide Cancer Research [grant number 16-1303] and The Dunhill Medical Trust [grant number R463/0216]. The authors would like to acknowledge CMAC National Facility, housed 
within the University of Strathclyde's Technology and Innovation Centre, and funded with a UK Research Partnership Institute Fund (UKRPIF) for the access to the circular dichroism spectrometer.

\section{ASSOCIATED CONTENT}

\section{Supporting Information}

Figures S1- S10, Table S1 (PDF)

\section{AUTHOR INFORMATION \\ Corresponding Author \\ *C.Dufes@strath.ac.uk}

\section{Notes}

The authors declare no competing financial interests. 


\section{References}

1 P.Y. Teo, W. Cheng, J.L. Hedrick and Y.Y. Yang, Adv. Drug Deliv. Rev., 2016, 98, 4163.

2 B. Al-Lazikani, U. Banerji and P. Workman, Nat. Biotechnol., 2012, 30, 679-692.

3 S. Kumar, R. Acharya, U. Chatterji and P. De, Langmuir, 2013, 29(49), 15375-15385.

4 D. Luo and W.M. Saltzman, Nat. Biotechnol., 2000, 18, 33-37.

5 S. Somani and C. Dufès, Nanomedicine, 2014, 9, 2403-2414.

6 S. Mura, J. Nicolas and P. Couvreur, Nat. Mater., 2013, 12, 991-1003.

7 J. Yang, Q. Zhang, H. Chang and Y. Cheng, Chem. Rev., 2015, 115, 5274-5300.

8 M. Liu and J.M. Fréchet, Pharm. Sci. Technol. Today, 1999, 2, 393-401.

9 B.H. Zinselmeyer, S.P. Mackay, A.G. Schätzlein and I.F. Uchegbu, Pharm. Res., 2002, 19, 960-967.

10 S. Koppu, Y.J. Oh, R. Edrada-Ebel, D.R. Blatchford, L. Tetley, R.J. Tate and C. Dufès, J. Control.Release, 2010, 143, 215-221.

11 F. Lemarié, D.R. Croft, R.J. Tate, K.M. Ryan and C. Dufès, Biomaterials, 2012, 33, 2701-2709.

12 N. Altwaijry, S. Somani, J.A. Parkinson, R.J. Tate, P. Keating, M. Warzecha, G.R. Mackenzie, H.Y. Leung and C. Dufès, Drug Deliv., 2018, 25, 679-689.

13 F.F. Davis, Adv. Drug Deliv. Rev., 2002, 4, 457-458.

14 P.J. Photos, L. Bacakova, B. Discher, F.S. Bates and D.E. Discher, J. Control. Release, 2003, 90, 323-334.

15 Y. Kim, A.M. Klutz and K.A. Jacobson, Bioconjug. Chem., 2008, 19, 1660-1672.

16 P. Laskar, B. Saha, S.K. Ghosh and J. Dey, RSC Adv., 2015, 5,16265-16276.

17 S. Somani, P. Laskar, N. Altwaijry, P. Kewcharoenvong, C. Irving, G. Robb, B.S. Pickard, and C. Dufès, Sci.Rep., 2018, 8, 9410.

18 L.F. Liu, S.D. Desai, T.K. Li, Y. Mao, M.E.I. Sun and S.P. Sim, Ann. New York Acad. Sci., 2000, 922, 1-10.

19 P. Laskar, S. Samanta, S.K. Ghosh and J. Dey, J. Colloid Interface Sci., 2014, 430, $305-$ 314. 
20 R.B. Greenwald, A. Pendri, C. Conover, C. Gilbert, R. Yang and J. Xia, J. Med. Chem., 1996, 39, 1938-1940.

21 V.R. Caiolfa, M. Zamai, A. Fiorino, E. Frigerio, C. Pellizzoni, R. d'Argy, A. Ghiglieri, M.G. Castelli, M. Farao, E. Pesenti and M. Gigli, J. Control. Release, 2000, 65, 105-119.

22 A.V. Yurkovetskiy, A. Hiller, S. Syed, M. Yin, X.M. Lu, A.J. Fischman and M.I. Papisov, Mol. Pharm., 2004, 1, 375-382.

23 A.B. Fleming, K. Haverstick and W.M. Saltzman, Bioconjug. Chem., 2004, 15, 13641375 .

24 H. Maeda, Adv. Enzyme Regul., 2001, 41, 189-207.

25 A.G. Cheetham, P. Zhang, Y.A. Lin, L.L. Lock and H. Cui, J. Am. Chem. Soc., 2013, 135, 2907-2910.

26 X.Q. Li, H.Y. Wen, H.Q. Dong, W.M. Xue, G.M. Pauletti, X.J. Cai, W.J. Xia, D. Shi and

Y.Y. Li, Chem. Commun., 2011, 47, 8647-8649.

27 L. Qiu, Q. Liu, C.Y. Hong and C.Y. Pan, J. Mater. Chem. B, 2016, 4, 141-151.

28 W. Ma, A.G. Cheetham and H. Cui, Nano Today, 2016, 11, 13-30.

29 J.M. Criscione, B.L. Le, E. Stern, M. Brennan, C. Rahner, X. Papademetris and T.M.

Fahmy, Biomaterials, 2009, 30, 3946-3955.

30 M. Filippi, D. Patrucco, J. Martinelli, M. Botta, P. Castro-Hartmann, L. Tei and E. Terreno, Nanoscale, 2015, 7, 12943-12954.

31 B.B. Wang, X. Zhang, X.R. Jia, Z.C. Li, Y. Ji, L. Yang and Y. Wei, J. Am. Chem. Soc., 2004, 126, 15180-15194.

32 K. Tsuda, G.C. Dol, T. Gensch, J. Hofkens, L. Latterini, J.W. Weener, E.W. Meijer and

D. Schryver, J. Am. Chem. Soc., 2000, 122, 3445-3452.

33 P. Laskar, S. Somani, N. Altwaijry, M. Mullin, D. Bowering, M. Warzecha, P. Keating, R.J. Tate, H.Y. Leung and C. Dufès, Nanoscale, 2018, 10, 22830-22847.

34 P. Kuppusamy, H. Li, G. Ilangovan, A.J. Cardounel, J.L. Zweier, K. Yamada, M.C.

Krishna and J.B. Mitchell, Cancer Res., 2002, 62, 307-312.

35 M. Huo, J. Yuan, L. Tao and Y. Wei, Polym. Chem., 2014, 5, 1519-1528.

36 P. Laskar, J. Dey and S.K. Ghosh, J. Colloid Interface Sci., 2017, 501, 22-33. 
37 Z. Zhou, Y. Shen, J. Tang, M. Fan, E.A. Van Kirk, W.J. Murdoch and M. Radosz, Adv. Funct. Mater., 2009, 19, 3580.

38 F. Yuan, M. Dellian, D. Fukumura, M. Leunig, D.A. Berk, V.P. Torchilin and R.K. Jain, Cancer Res., 1995, 55, 3752-3756.

39 R.I. Mahato, L.C. Smith and A. Rolland, Adv. Genet. 1999, 41, 95-156.

40 S. Mandal, J. Kuchlyan, S. Ghosh, C. Banerjee, N. Kundu, D. Banikm and N. Sarkar, J. Phys. Chem. B, 2014, 118, 5913-5923.

41 M.L. Horng, J.A. Gardecki, A. Papazyan and M. Maroncelli, J. Phys. Chem., 1995, 99, 17311-17337.

42X. Liu, D. Hu, Z. Jiang, J. Zhuang, Y. Xu, X. Guo and S. Thayumanavan, Macromolecules, 2016, 49, 6186-6192.

43 G. Thiagarajan, A. Ray, A. Malugin and H. Ghandehari, Pharm. Res., 2010, 27, 23072316.

44 O.Y. Zolotarskaya, L. Xu, K. Valerie and H. Yang, RSC Adv., 2015, 5, 58600-58608.

45 M.E. Fox, S. Guillaudeu, J.M. Fréchet, K. Jerger, N. Macaraeg and F.C. Szoka, Mol.

Pharm., 2009, 6, 1562-1572

46Z. Zhou, X. Ma, E. Jin, J. Tang, M. Sui, Y. Shen, E.A. Van Kirk, W.J. Murdoch and M.

Radosz, Biomaterials, 2013, 34, 5722-5735.

47 A.P. Schenning, C. Elissen-Roman, J.W. Weener, M.W. Baars, S.J. van der Gaast and

E.W. Meijer, J. Am. Chem. Soc., 1998, 120, 8199-8208.

48 X. Cai, C. Dong, H. Dong, G. Wang, G.M. Pauletti, X. Pan, H. Wen, I. Mehl, Y. Li and D. Shi, Biomacromolecules, 2012, 13, 1024-1034.

49 T.L. Nguyen, T.H. Nguyen, C.K. Nguyen and D.H. Nguyen, BioMed Res. Int., 2017, 2017, 8589212.

50 Y. Li, R. Liu, J. Yang, G. Ma, Z. Zhang and X. Zhang, Biomaterials, 2014, 35, 97319745. 


\section{Supporting information}

\section{Camptothecin-based dendrimersomes for gene delivery and redox-responsive drug delivery to cancer cells}

Partha Laskar, ${ }^{a}$ Sukrut Somani, ${ }^{\text {a }}$ Sara Jane Campbell, ${ }^{a}$ Margaret Mullin, ${ }^{\text {b }}$ Patricia Keating, ${ }^{\text {c }}$ Rothwelle J. Tate, ${ }^{a}$ Craig Irving, ${ }^{c}$ Hing Y. Leung, ${ }^{\mathrm{e}}$ and Christine Dufès, ${ }^{* a}$

a Strathclyde Institute of Pharmacy and Biomedical Sciences, University of Strathclyde, 161 Cathedral Street, Glasgow G4 0RE, United Kingdom.

${ }^{\mathrm{b}}$ College of Medical, Veterinary and Life Sciences, University of Glasgow, Glasgow G12 8QQ, United Kingdom.

${ }^{c}$ Department of Pure and Applied Chemistry, University of Strathclyde, 295 Cathedral Street, Glasgow G1 1XL, United Kingdom

d Cancer Research UK Beatson Institute, Garscube Estate, Switchback Road, Bearsden, Glasgow, G61 1BD, United Kingdom.

\section{Corresponding Author}

* Corresponding author: Christine Dufès

Strathclyde Institute of Pharmacy and Biomedical Sciences, University of Strathclyde, 161

Cathedral Street, Glasgow G4 0RE, United Kingdom

Phone: 44 -141 5483796

Fax: $44-1415522562$

E-mail: $\underline{\text { C.Dufes@strath.ac.uk }}$ 


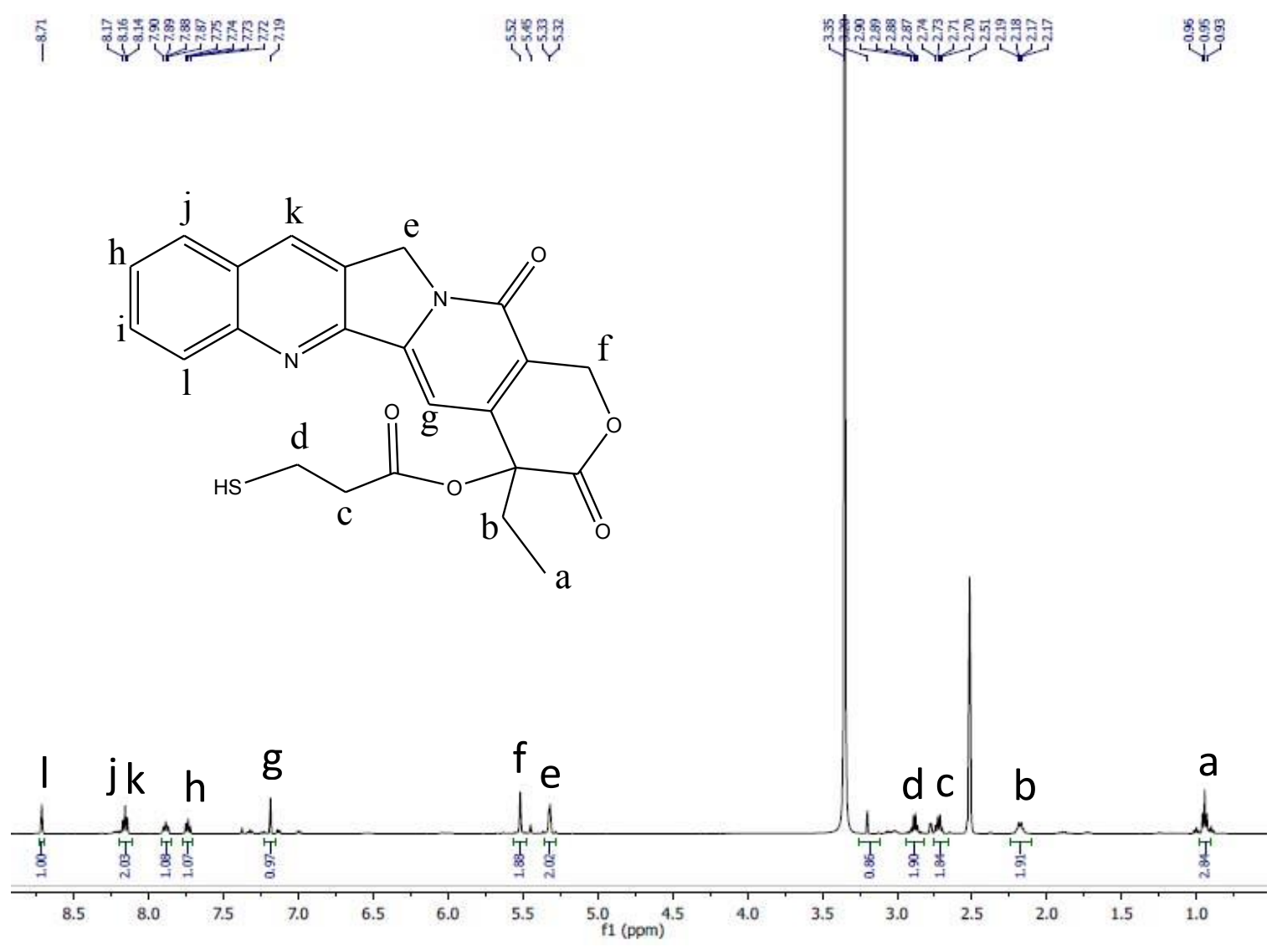

Figure S1. ${ }^{1} \mathrm{H}-\mathrm{NMR}$ spectrum of thiolated camptothecin CPT-SH (in DMSO-d6, $500 \mathrm{MHz}$ ).

${ }^{1} \mathrm{H}$ NMR (500 MHz, DMSO-d6, $\delta$ ppm): $8.71(\mathrm{~s}, 1 \mathrm{H}), 8.16(\mathrm{~m}, 2 \mathrm{H}), 7.87-7.90(\mathrm{~m}, 1 \mathrm{H}), 7.72-7.75(\mathrm{~m}, 1 \mathrm{H})$, $7.19(\mathrm{~s}, 1 \mathrm{H}), 5.52(\mathrm{~s}, 2 \mathrm{H}), 5.32(\mathrm{~s}, 2 \mathrm{H}), 3.20(\mathrm{~m}, 1 \mathrm{H}), 2.87-2.90(\mathrm{~m}, 2 \mathrm{H}), 2.70-2.74(\mathrm{~m}, 2 \mathrm{H}), 2.17-2.19(\mathrm{~m}$, $2 \mathrm{H}), 0.93-0.96(t, 3 \mathrm{H})$. 


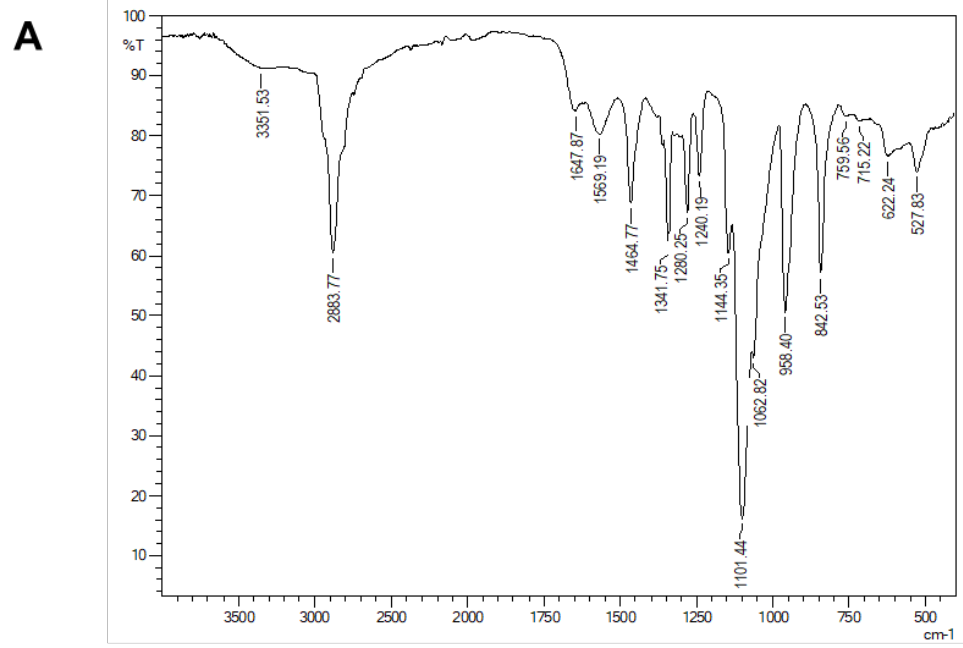

B

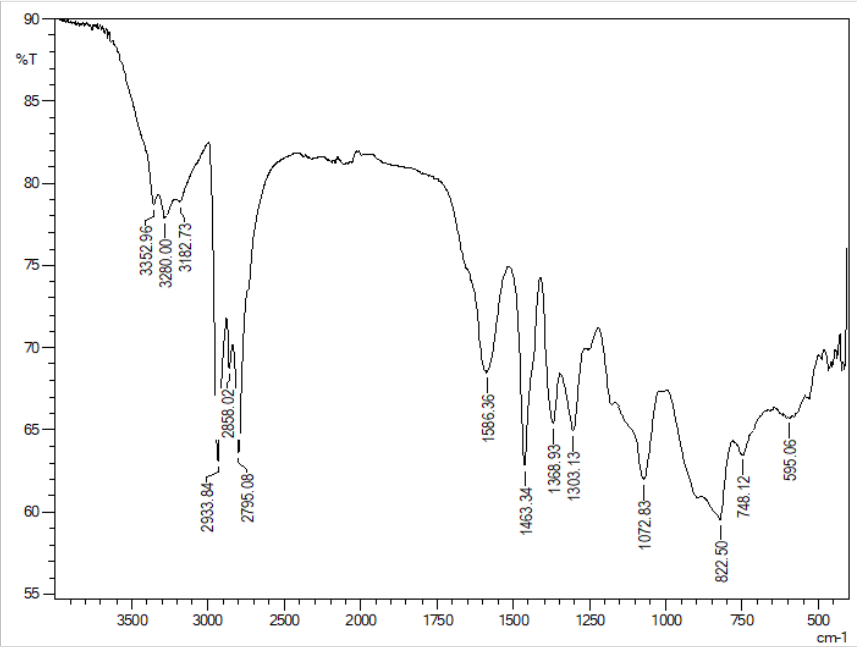

C

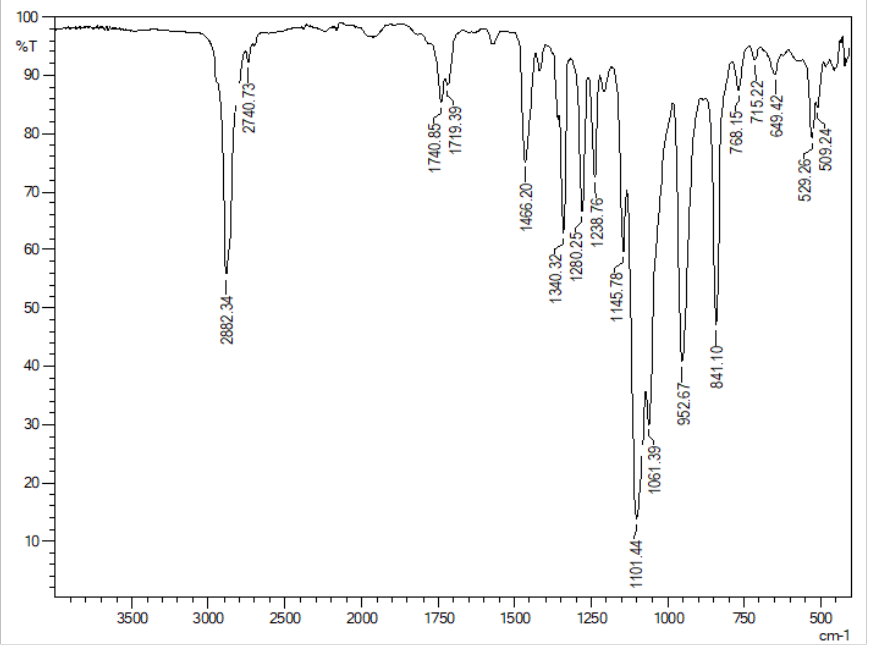

Figure S2. FTIR spectrum of CPT-bearing PEGylated DAB dendrimer (DPSSC) (A), DAB (B), and OPSS-PEG-SCM (C) 


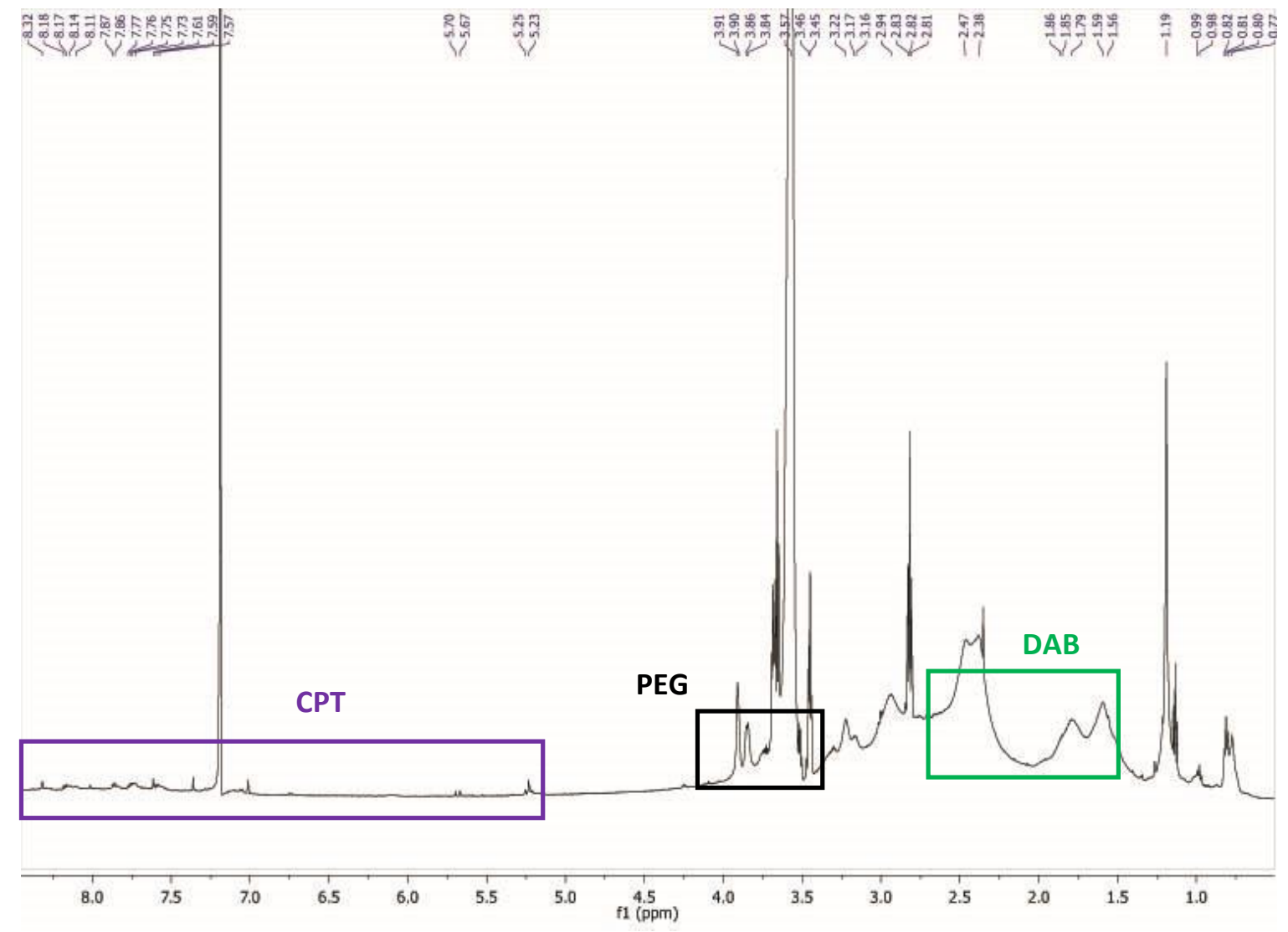

Figure S3. ${ }^{1} \mathrm{H}-\mathrm{NMR}$ spectrum of DPSSC dendrimer $\left(\mathrm{CDCl}_{3}, 600 \mathrm{MHz}\right)$. 


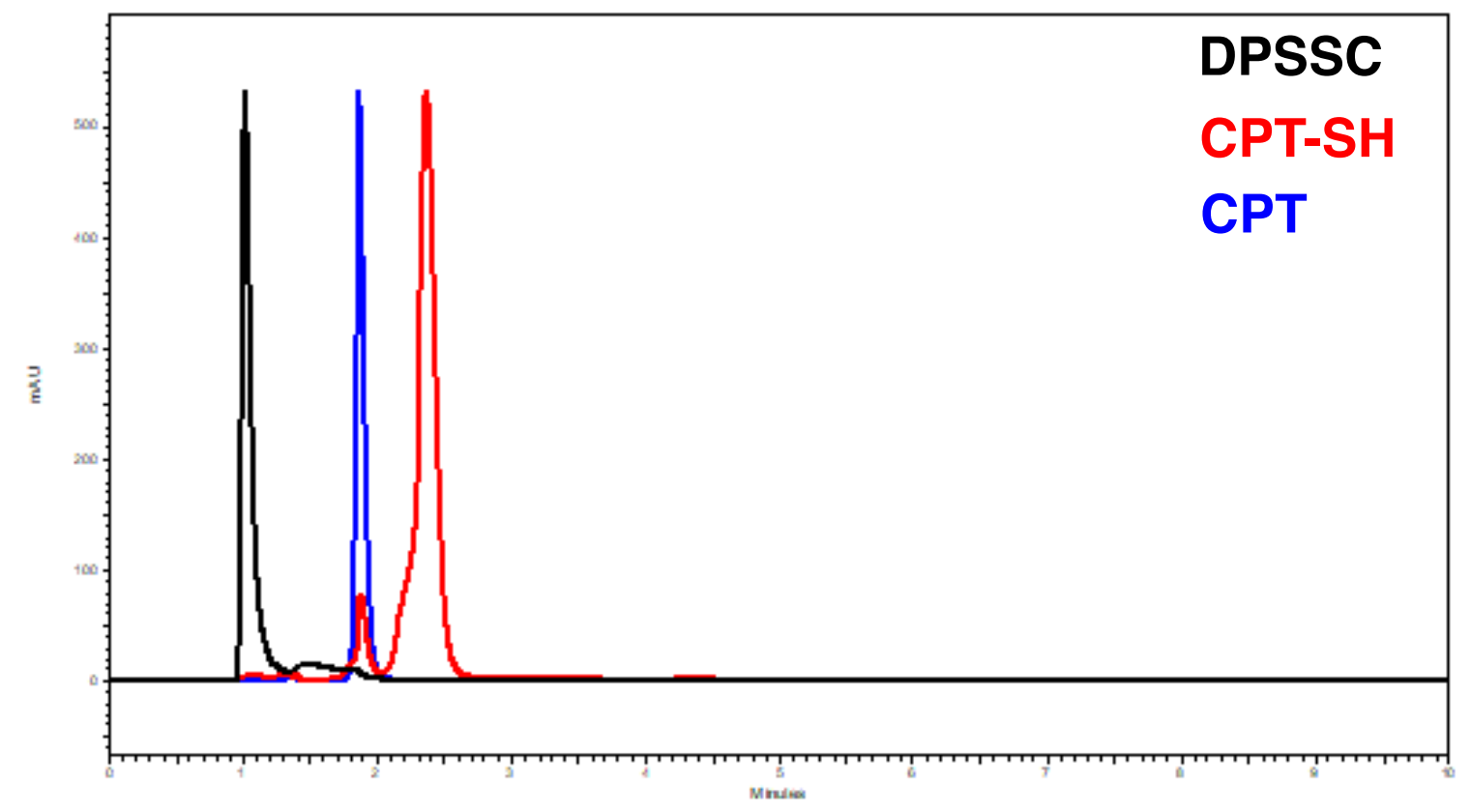

Figure S4. HPLC chromatogram of DPSSC (controls: CPT and CPT-SH) 
A

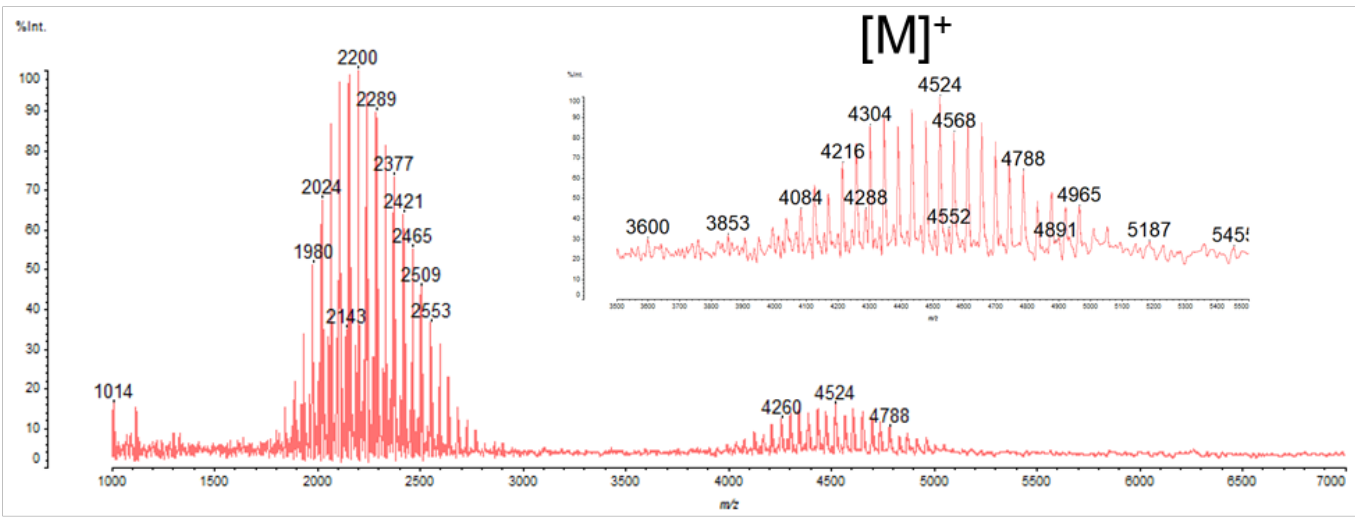

B
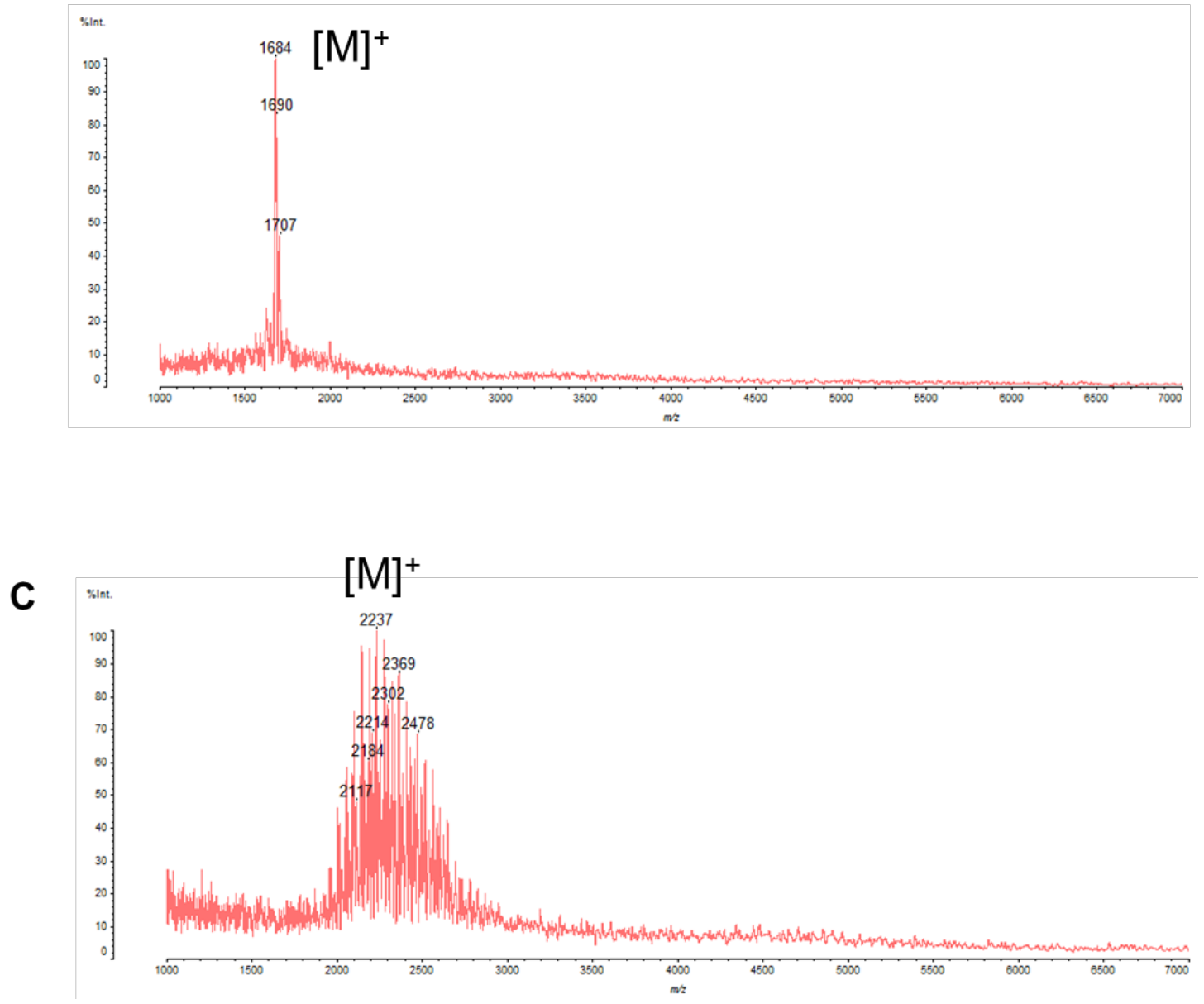

Figure S5. MALDI-TOF MS spectra of DPSSC (A), DAB (B) and OPSS-PEG-SCM (C) 


\section{S1. CPT loading calculation}

The CPT loading in DPSSC was calculated as the weight of conjugated CPT expressed as a percentage of the total average molecular weight:

CPT loading $(\%)=\left\{\left(\mathrm{n} \times \mathrm{MW}_{\text {conjugated } \mathrm{CPT}}\right) /[\mathrm{M}]^{+}\right\} \times 100$

Where $\mathrm{n}$ is the number of CPT conjugated to modified dendrimer, $\mathrm{MW}_{\text {conjugated CPT }}$ is the molecular weight of conjugated CPT $(347.35 \mathrm{~g} / \mathrm{mol})$ and $[\mathrm{M}]^{+}$is the average molecular weight of the modified dendrimer (4480 g/mol), as obtained from MALDI-TOF mass spectrometry analysis.

CPT loading in DPSSC $(\%)=\{(1 \times 347.35) / 4480\} \times 100=7.75 \%$

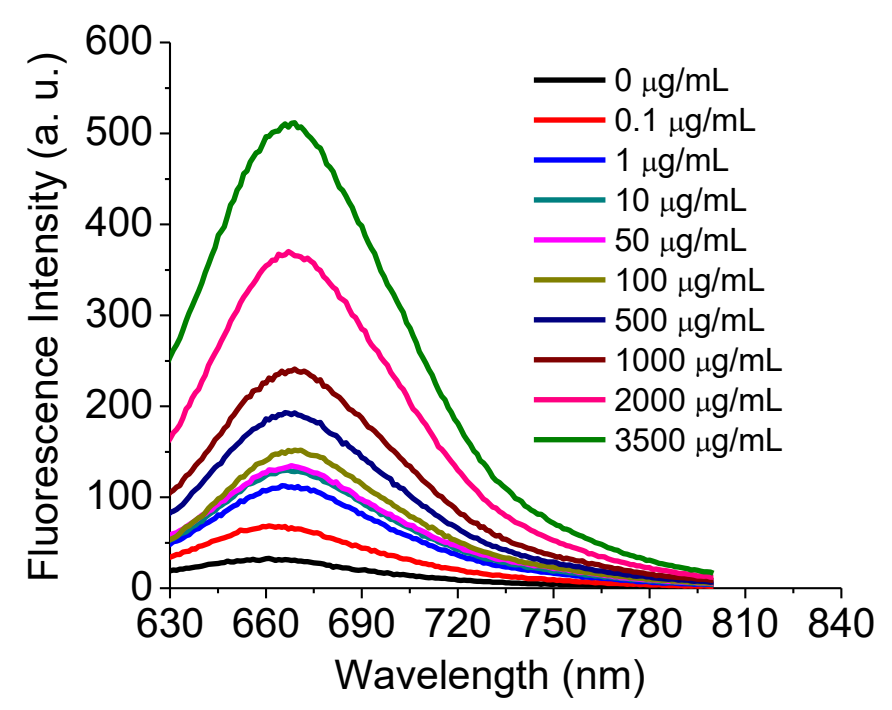

Figure S6. Fluorescence spectra of Nile Red in presence of DPSSC at various concentrations in phosphate buffer (pH 7.4) 


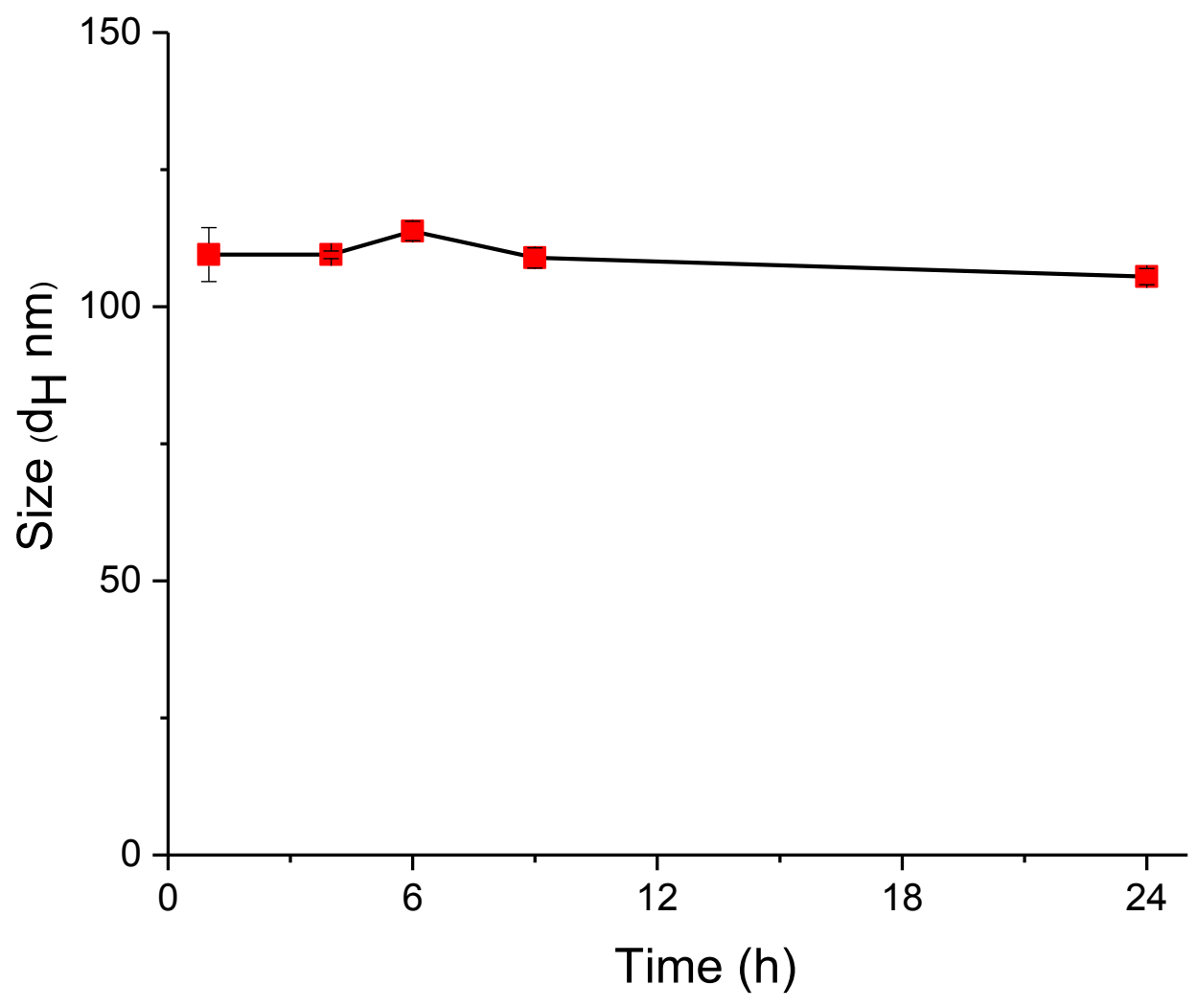

Figure S7. Size of DPSSC ( $2 \mathrm{mg} / \mathrm{mL})$ incubated in presence of complete medium containing $10 \% \mathrm{FBS}$ at $37^{\circ} \mathrm{C}$ at various time intervals $(\mathrm{n}=3)$. 
A DPSSC-No GSH

1h, 6h, 24h, 48h, 72h, 96h, 120h, 144h, 168h

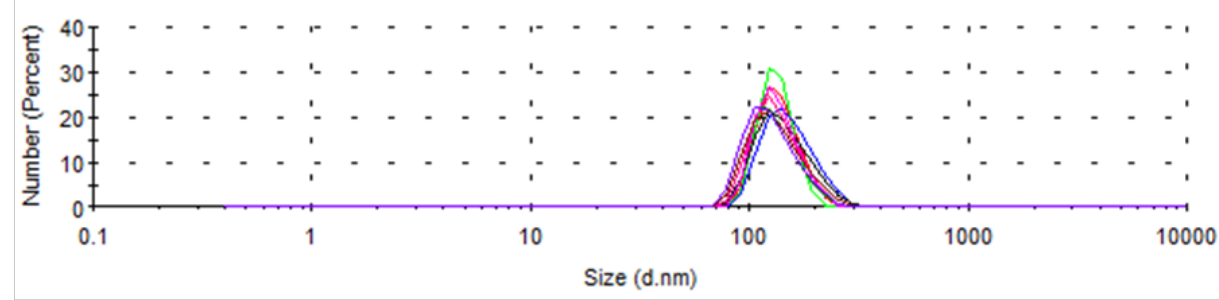

B DPSSC-10 $\mu \mathrm{M} \mathrm{GSH}$

1h, 6h, 24h, 48h, 72h, 96h, 120h, 144h, 168h

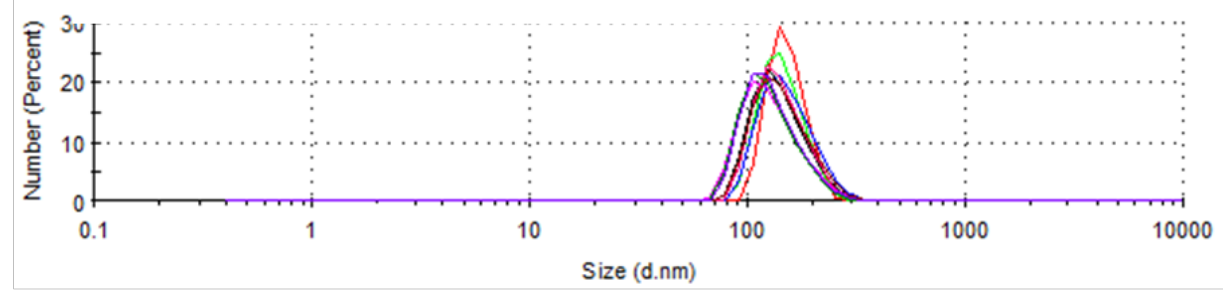

C DPSSC-10 mM GSH

1h, 6h, 24h, 48h, 72h, 96h, 120h, 144h, 168h

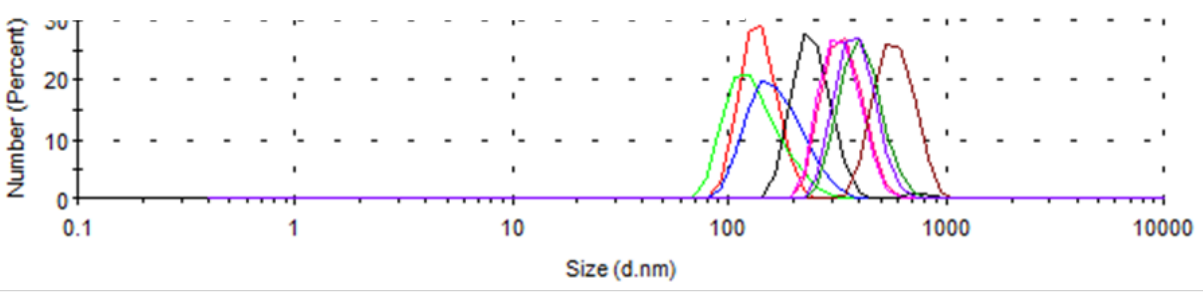

D DPSS-50 $\mathrm{mM} \mathrm{GSH}$

1h, 6h, 24h, 48h, 72h, 96h, 120h, 144h, 168h

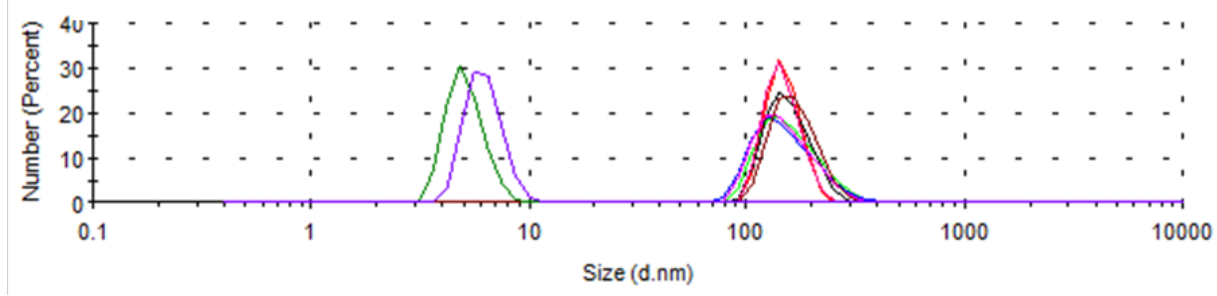

Figure S8. Size distribution of DPSSC ( $1 \mathrm{mg} / \mathrm{mL}$, phosphate buffer $(\mathrm{pH} 7.4)$ in presence of various GSH concentrations: 0 (A), $10 \mu \mathrm{M}$ (B), $10 \mathrm{mM}$ (C) and $50 \mathrm{mM}$ (D) 
Table S1. Zeta potential of DPSSC (1 mg/mL, phosphate buffer of $\mathrm{pH} 7.4)$ incubated in presence of various $\mathrm{GSH}$ concentrations $(0,10 \mu \mathrm{M}, 10 \mathrm{mM}$ and $50 \mathrm{mM})$ at $37^{\circ} \mathrm{C}$ after different time intervals $(\mathrm{n}=3)$

\begin{tabular}{ccc}
\hline \multirow{2}{*}{$\begin{array}{c}\text { DPSC solutions } \\
(\mathbf{1} \mathbf{~ m g} / \mathbf{m L})\end{array}$} & After $\mathbf{6 ~ h}$ & After $\mathbf{7}$ days \\
\cline { 2 - 3 } & & \\
\hline No GSH & $4.21 \pm 0.65$ & $4.97 \pm 0.49$ \\
$\mathbf{1 0} \boldsymbol{\mu M ~ G S H}$ & $\mathrm{NA}$ & $4.09 \pm 0.64$ \\
$\mathbf{1 0} \mathbf{~ m M ~ G S H}$ & $\mathrm{NA}$ & $0.46 \pm 0.06$ \\
$\mathbf{5 0} \mathbf{~ m M ~ G S H}$ & $\mathrm{NA}$ & $23.1 \pm 2.55$ \\
\hline
\end{tabular}




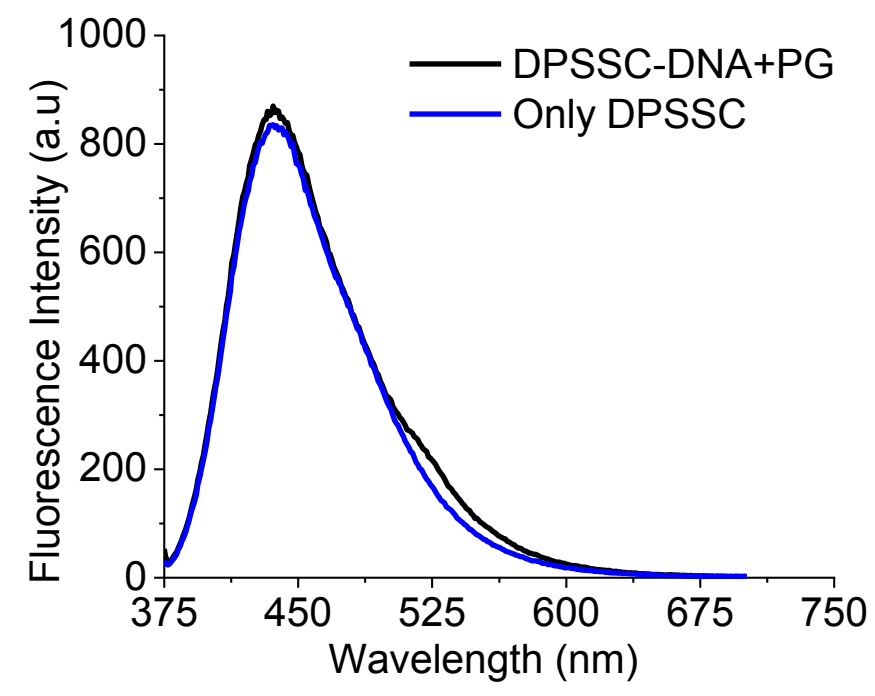

Figure S9. Fluorescence emission spectra $\left(\lambda_{\text {exc }}: 365 \mathrm{~nm}\right.$ ) of DPSSC complexed with DNA at DPSSC: DNA weight ratio of 20:1, in presence of PicoGreen (PG) (control: DPSSC only $(200 \mu \mathrm{g} / \mathrm{mL})$ ). The amount of DNA was fixed at $10 \mu \mathrm{g}$ for each complex. 

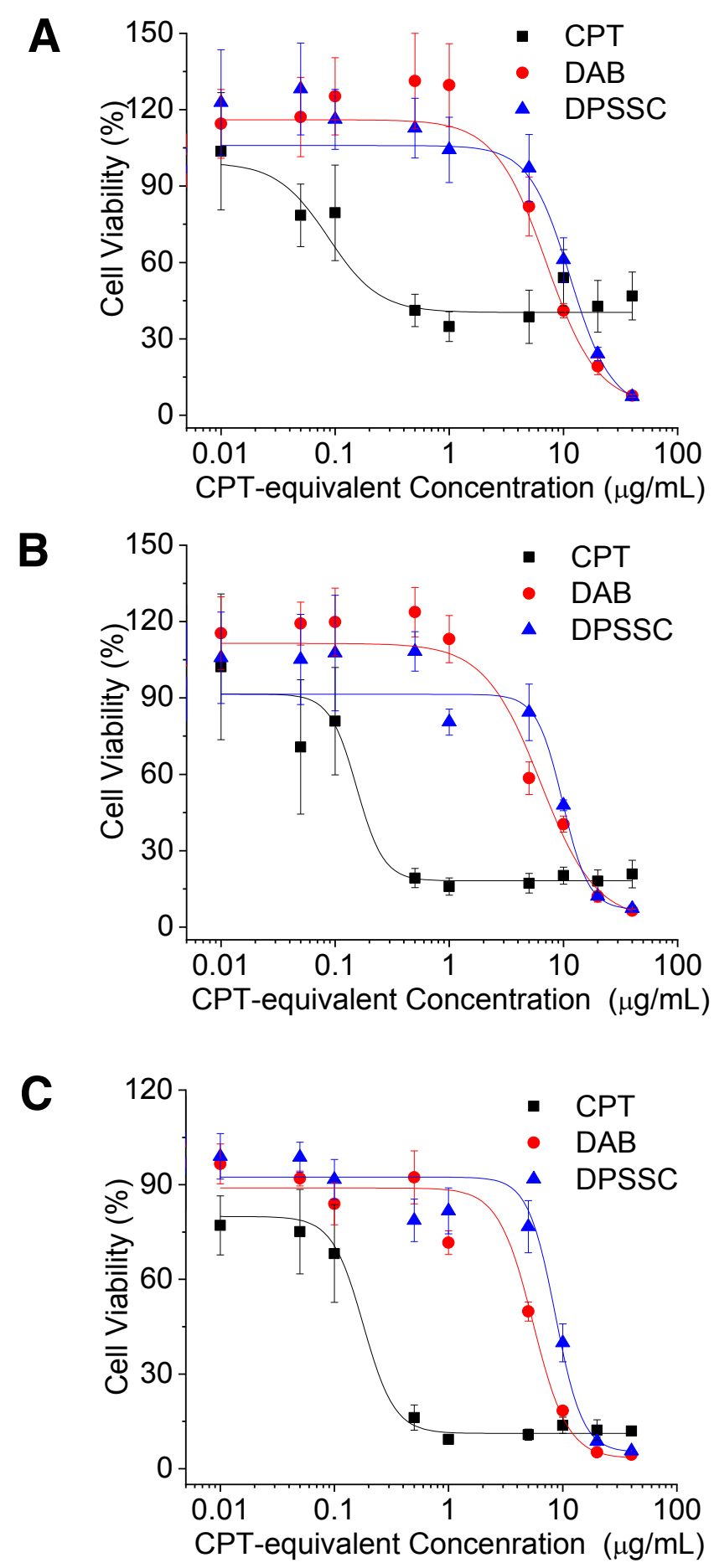

Figure S10. Cell viability of DPSSC, DAB and free CPT on PC3-Luc human prostate cancer cells at various concentrations after 24 (A) 48 (B) and $72 \mathrm{~h}$ (C) of incubation. The data points are mean \pm SD. (n $=5)$. 
A

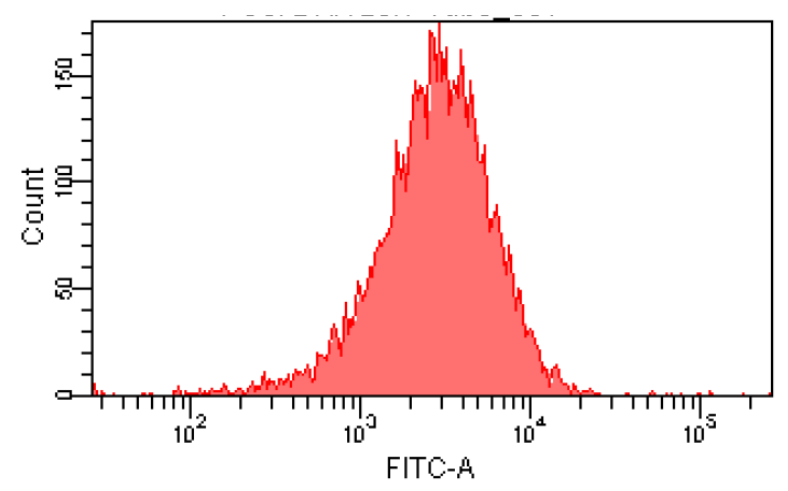

\section{C}

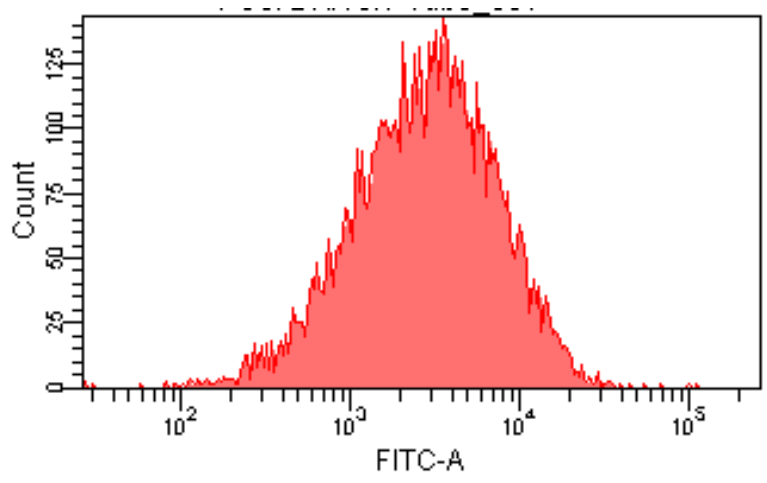

E

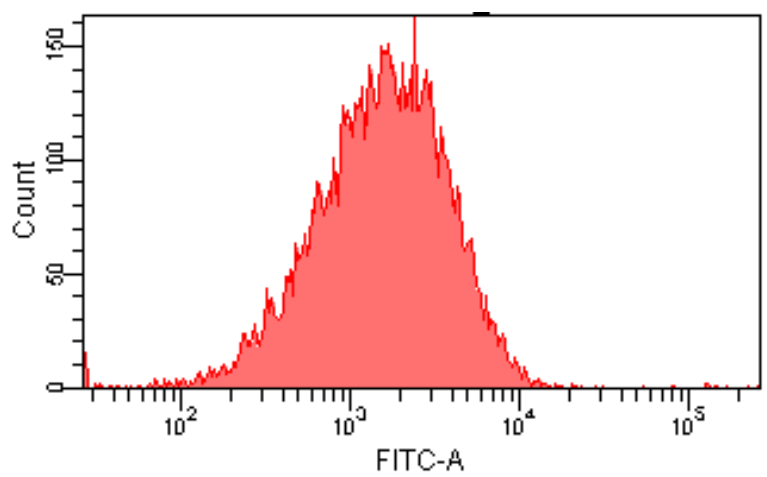

B

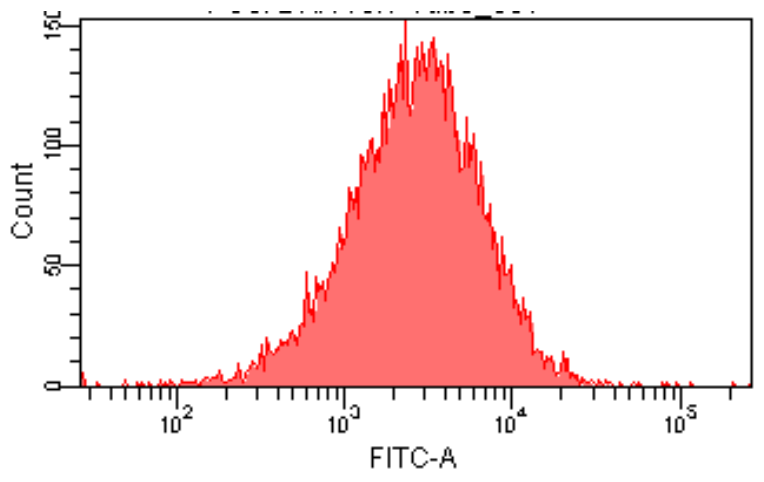

D
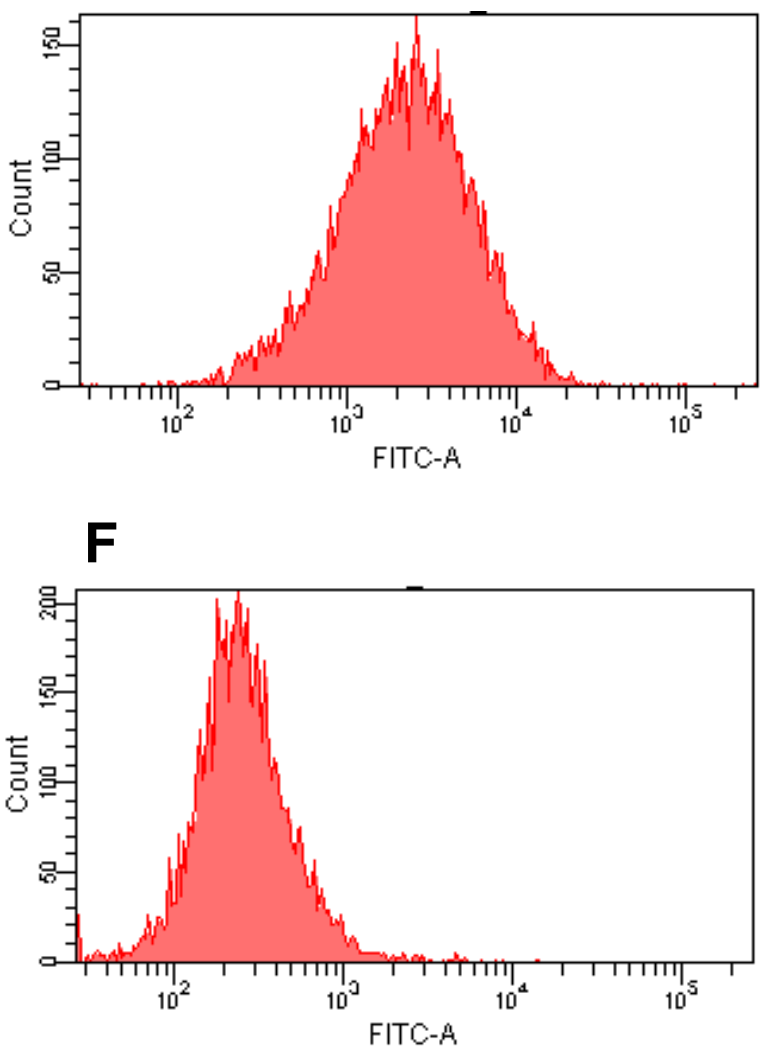

Figure S11. Flow cytometry histograms of PC3-Luc cells following 2 hours incubation with DPSSC-DNA complexes (dendrimer: DNA weight ratios: 20:1 (A), 10:1 (B), 5:1 (C) and 10:1 (D)) (controls: DAB dendriplex (dendrimer: DNA weight ratio 5:1 (E)) and DNA solution (F)) 